\title{
Füze Teknolojisi Kontrol Rejimi: ABD Merkezli Hegemonik Bir Yapıdan Normatif Bir Yapıya Geçişin Önemi
}

\author{
The Missile Technology Control Regime:
} The Necessity of Transitioning from a US-Centered Hegemonic Framework to a Normative One

\author{
Eray ALIM*
}

\section{$\ddot{O} z$}

Füze Teknolojisi Kontrol Rejimi (FTKR), füze ve kitle imha silahı tehdidini önlemede başat girişimlerden biridir. Bu oluşumun taşıyıcı gücü ise ABD'dir. Bu ülke, yaptırım baskistyla Rusya, Hindistan ve Brezilya dâhil birçok farklı ülkenin FTKR kaidelerine uygun davranmasını sağlayabilmiştir. Bu hususa rağmen, belirli anlarda ABD'nin FTKR kaidelerini bizzat kendisinin ihlal etmesi, hegemonik güçlerin kuralları çiğnemenin yaratacağı itibar kaybına aldırmaksızın kendi çıkarlarını ön plana alabildiklerini göstermektedir. Kitle imha silahı ve füze tehdidinin daha etkili bir şekilde önlenmesi için ise FTKR'nin ABD merkezli bir "seçkinler kulübü" imajından kurtulmast gerekmektedir. Bu oluşumun ABD merkezlilikten kurtulması, kendi kurumsal yapısı dâhilinde bir kontrol ve yaptırım mekanizmasina sahip olmasin gerekli kllmaktadır. Kurumsallaşmanın güçlendirilmesine eş zamanl şekilde, FTKR kapsaminda devletlerin füze tehdidine dair norm ve prensipleri içselleştirmeleri ve bu minvalde normatif bir dönüşüm geçirmeleri sağlanmalıdır. Bu çalışmada vurgulandiğı üzere, FTKR'nin meşruiyeti ve

\footnotetext{
* Dr., Batman Üniversitesi, İktisadi ve İdari Bilimler Fakültesi, Siyaset Bilimi ve Kamu Yönetimi Bölümü, ORCID ID: 0000-0001-7543-8021, e-posta: erayalim@ hotmail.com.

Geliş Tarihi / Submitted: 12.03.2020 Kabul Tarihi / Accepted: 28.09.2020
} 
822

Güvenlik Stratejileri

Cilt: 16

Say1: 36

etkinliği için ABD merkezli faydacı-hegemonik bir yapıdan normatif bir yapıya geçis büyük önem arz etmektedir.

Anahtar Kelimeler: Füze Teknolojisi Kontrol Rejimi, Uluslararast Rejimler, Füze Tehdidi, Kitle Imha Silahları, Amerika Birleşik Devletleri.

\section{Abstract}

The Missile Technology Control Regime (MTCR) is one of the leading initiatives in the realm of tackling threats related to missiles and weapons of mass destruction. The US acts as a driving force within this organization. Through its sanction power, the US managed to compel countries such as Russia, India and Brazil into adhering to the principles of the MTCR. On the other hand, in certain occasions, the US violated the principles of the MTCR itself, which demonstrates that hegemonic powers may choose to privilege their own interests over regime rules despite the risk of suffering consequential reputational costs. It is in this respect essential for a more effective handling of the threat of weapons of mass destruction and missile proliferation that the MTCR shed the image of a US-centered "elite club". Overcoming U.S-centeredness requires forming inspection and sanctions mechanisms within the institutional framework of the MTCR. Along with strengthening institutionalization, it also essential for the MTCR's effectiveness that this organization enables the normative transformation of states, implying the facilitation of the internalization of norms and principles by states regarding missile threat. As stressed in this work, the MTCR's legitimacy and effectiveness necessitate a transition from a US-centered utilitarian-hegemonic framework into a normative one.

Keywords: Missile Technology Control Regime, International Regimes, Missile Threat, Weapons of Mass Destruction, The United States of America.

\section{Giriş}

Silahlanma sorunu uluslararası güvenlik alanındaki temel meselelerden biridir. Devletlerin ulusal çıkarlarını korumak için silahlanma yolunda ilerlemeleri, güç dengesinin bozulması, aralarındaki ilişkilerin istikrarsızlaşması ve uluslararası güvenliğin tehdit edilmesi gibi riskleri beraberinde getirmektedir. Silahlanmanın özellikle kitle 
Füze Teknolojisi Kontrol Rejimi:

ABD Merkezli Hegemonik Bir Yapıdan Normatif Bir Yapıya Geçişin Önemi

imha silahlarıyla icra edilmesi, uluslararası ilişkilerde risk katsayısını iyice arttıran bir işlev görmektedir. ${ }^{1}$ Özellikle Soğuk Savaş yıllarında iki süper gücün geliştirdikleri geniş nükleer silah envanterleri, olası bir savaş durumunda dünyanın karşılaşabileceği yıkımın ne denli büyük olabileceğini gözler önüne sermiştir. Nitekim ortadaki risklerin ciddiyetinin farkına varılmasıyla, bir süre sonra güven arttırıcı mekanizmalar devreye sokulmuş ve iki süper güç arasında imzalanan SALT, START ve INF gibi antlaşmalarla risk ve tehditler kontrol altına alınmaya çalışılmıştır. Uluslararası siyasetin aktörleri, ikili bir çerçevede olduğu gibi, çok taraflı inisiyatiflerle de kitle imha silahlarından kaynaklanan tehdidin önüne geçmeye çalışmışlardır. $\mathrm{Bu}$ minvalde, Nükleer Silahların Yayılmasının Önlenmesi Antlaşması (NPT), Avustralya Grubu, Nükleer Tedarikçiler Grubu, Biyolojik Silahlar Konvansiyonu ve Kitle İmha Silahlarının Yayılmasına Karşı Güvenlik İnisiyatifi gibi girişimlerle; kimyasal, biyolojik ve nükleer silahlardan oluşan kitle imha silahlarının neden olduğu tehdidinin önüne geçilmeye çalışılmıştır.

Devletleri bu gibi girişimleri hayata geçirmeye sevk eden nedenler arasında, hiç şüphesiz, yirminci yüzyılda yaşanan iki Dünya Savaşı ve bu savaşlarda kullanılan kitle imha silahlarının neden olduğu acı tecrübeler etkili olmuştur. Birinci Dünya Savaşı'nda kullanılan kimyasal silahların insan vücudu üzerindeki etkileri görülerek, 1925 'te Milletler Cemiyeti çatısı altında Cenova Protokolü kabul edilmiş ve savaşlarda zehirli gazların kullanılması yasaklanmıştır. ${ }^{2}$ Fakat İkinci Dünya Savaşı sırasında, kitlesel katliam bakımından daha da büyük tahribat yaratma kapasitesine sahip olan nükleer silahın kullanılmasıyla, kitle imha silahları

\footnotetext{
${ }^{1}$ Öte yandan, özellikle nükleer silahlar özelinde kitle imha silahlarının devletler arası ilişkilerde istikrar sağlayan bir rol oynadığını iddia eden yazarlar da mevcuttur. Örnek olarak bkz; Kenneth N. Waltz, "Why Iran Should Get the Bomb: Nuclear Balancing Would Mean Stability", Foreign Affairs, 2012, Cilt: 91, No: 4, s. 2-5.

2 "1925 Geneva Protocol", https://www.un.org/disarmament/wmd/bio/1925-genevaprotocol/\#: :text=The\%201925\%20Geneva\%20Protocol\%20prohibits,force\%20on\%2 08\%20February\%201928 (Erişim Tarihi: 28.09.2020).
}

\section{3}

Güvenlik Stratejileri

Cilt: 16

Say1: 36 
824

Güvenlik Stratejileri

Cilt: 16

Sayı: 36 nedeniyle toplumların topyekûn bir şekilde imha edilebileceği gerçeği tecrübe edilmiştir. Soğuk Savaş sürecini kapsayan zaman diliminde ise NPT gibi çok taraflı antlaşmalar hayata geçirilerek, nükleer silahlar hepten ortadan kaldırılamasa da en azından yayılmasının önlenmesi ve nükleer enerjinin barışçıl amaçlarla kullanılmasının başarılması hedeflenmiştir. $\mathrm{Bu}$ gibi inisiyatiflerle, kısmi de olsa, belirli başarılar sağlanmıştır. Mevcut konjonktüre kadar olan sürede NPT'nin dışında kalan Hindistan, Pakistan, İsrail ve 2003 'te NPT'den çekilen Kuzey Kore gibi az sayıda ülke nükleer silah geliştirebilmiştir. Kimyasal silahlar özelinde ise Irak-İ́ran Savaşı ve Suriye'deki iç savaş gibi hadiselerde dünyanın tepkisini çeken insan ölümleri yaşanmışsa da çatışma alanlarında kimyasal silah kullanıma teşebbüsleri görece sınırlı sayıda kalmıştır. ${ }^{3} \mathrm{Bu}$ bağlamda uluslararası toplumun, geniş çaplı katliamlara neden olacak kitle imha silahlarını tehdit olmaktan çıkarma teşebbüsü, bu yöndeki riskleri sıfıra indirgeyemediyse de önemli ölçüde azaltmaya yardımcı olmuştur.

Kitle imha silahlarının neden olduğu tehdidin önüne geçebilmek için, bu silahları sevk edebilecek unsurların kontrol altına alınması da büyük önem arz etmiştir. Devletlerin kitle imha silahlarını farklı coğrafyalara gönderebilecek uzun menzilli sistemler geliştirmeleri durumunda, bunun uluslararası güvenliğe dönük ciddi bir tehdit teşkil edileceği fark edilmiştir. Bu farkındalık çerçevesinde, füze sistemlerinin bir tehdit olmaktan çıkarılması için 1987'de Füze Teknolojisi Kontrol Rejimi (FTKR), 1995'te Wassenaar Düzenlemesi ve 2002'de Balistik Füzelerin Yayılmasına Karşı Lahey Davranış İlkeleri (HCOC) gibi girişimler hayata geçirilmiştir. Füze sistemlerinin uluslararası güvenliğe yönelttiği tehdidin önlenmesinde, bu çalışmanın da inceleme konusu olan FTKR, ağırlıklı bir konuma sahip olmuştur. Kitle imha silahlarından duyulan endişeye paralel olarak FKTR, 1987 y1lında G-7 oluşumunun çabasıyla hayata geçirmiştir. Her ne kadar FTKR kolektif bir girişim olarak hayata geçmişse de bu oluşumun kurulmasının esas itici gücü

${ }^{3}$ Arms Control Association, "Chemical Weapons: Frequently Asked Questions", June 2018, https://www.armscontrol.org/factsheets/Chemical-Weapons-Frequently-AskedQuestions (Erişim Tarihi: 20. 07.2020). 
Füze Teknolojisi Kontrol Rejimi:

ABD Merkezli Hegemonik Bir Yapıdan Normatif Bir Yapıya Geçişin Önemi

Amerika Birleşik Devletleri (ABD) olmuştur. 1980 yılında ABD başkanlığına gelen Ronald Reagan, kitle imha silahları ve füze tehdidinden hissedilen kaygılara paralel olarak bir çözüm arayışı içine girmiş ve bu arayış neticesinde 1982 yılında imzalanan 70. Ulusal Güvenlik Konseyi Kararnamesi ile FTKR'nin kuruluşunun temellerini atmıştır. Bu kararname gereğince, füze sistemlerinin yayılmasını önleme amaçlı yöntemler üzerinde araştırmalar yapılması ve bu konuda Büyük Britanya ile istişare içinde çalışılması kararları alınmıştır. ${ }^{4} 1987$ yılında diğer beş G-7 üyesinin de sürece dâhil olmalarıyla FTKR resmi olarak kurulmuş ve kısa süre içinde Soğuk Savaş'ın sonlanması sayesinde bu oluşum üye portföyü genişlemiş bir organizasyon olarak faaliyetlerine devam etmiştir.

Silahlanmanın uluslararası güvenliğe yönelttiği tehdit çerçevesinde FTKR, aktörlerin füze envanterlerini gerek ihracat gerekse teknoloji ve ekipman transferi yoluyla geliştirmelerini önlemeyi amaçlamaktadır. Teknik ve normatif birçok düzenlemeyi içinde barındıran FTKR, hem üye ülkeler hem de üye olan ve olmayan ülkeler arasında füze ve füze teknolojisi ve ekipmanı transferini belirli kaidelerle sinırlayan bir inisiyatiftir. FTKR uluslararası bir antlaşma üzerine temellenmese de içerdiği kurallara aykırı davranılması durumunda üye ülkelerin müstakil olarak uyguladıkları yaptırımlarla, ihlalkâr davranışlarda bulunan aktörlere geri adım attırılmaya çalışılmaktadır. Kurumsal yapısı itibariyle FTKR'nin kendine has bir kontrol mekanizmasının olmamas1 ve kolektif olarak yaptırım ve/veya farklı cezai uygulamalar devreye sokamaması, kaçınılmaz olarak bu oluşumun kuruluşuna ve işleyişine öncülük eden başat güç olarak ABD'yi ön plana taşımaktadır. Bu husus, ABD'nin tek taraflı olarak uyguladığ yaptırımlarla birçok farklı ülkeyi FTKR kaidelerine uygun davranmaya zorlamasında görülebilmektedir. ABD'nin bu organizasyon dâhilindeki hegemonik pozisyonuna rağmen, FTKR'nin Rusya ve Hindistan gibi ülkeleri bünyesine katabilmesi ve Brezilya ve Güney Afrika gibi ülkelerin füze programı

${ }^{4}$ Deborah A. Ozga, "A Chronology of the Missile Technology Control Regime", The Nonproliferation Review, 1994, Cilt: 1, No: 2, 66-93, s. 74. 
826

Güvenlik Stratejileri

Cilt: 16

Sayı: 36

geliştirmelerini engelleyebilmesi, bu oluşumun yadsınamaz başarılarıdır. Bununla birlikte, FTKR'nin batı menşeli bir "elitler kulübü" imajına sahip olması, içerdiği kaidelerin uygulanması noktasında eklektik davranışların sergilenebilmesi ve kendine ait bir denetim mekanizmasına ve süreklilik arz eden örgütsel yapıya sahip olmaması ise yetersiz kalınan noktalar olarak öne çıkmaktadır.

FTKR'nin olumlu icraatlarını ya da noksan kaldığı tarafları açılarken, uluslararası rejim kavramına dair teorik bir çerçevenin ortaya konulması önem arz etmektedir. Zira uluslararası rejimler, silahlanma, iklim değişikliği, uluslararası ticaret ve göç gibi farklı alanda, "konubazlı" olarak sorunların nasıl ele alındığının anlaşılması hususunda faydalı bir kavramsal çerçeve sunmaktadır. FTKR de "füze tehdidini önleme rejimi" olarak adlandırılabilecek alanda faaliyet göstermektedir. FTKR söz konusu alanda tek girişim olmasa da merkezi bir pozisyona sahip olduğu için, bu oluşumun "füze tehdidini önleme rejimi" bağlamında uluslararası güvenliğe dönük katkıları irdelenmesi gereken önemli bir konudur. Bu önemden hareketle bu çalışma, uluslararası rejim kavramının Uluslararası İlişkiler disiplininde nasıl ortaya çıktığını odaklanarak, fayda, çıkar ve norm kavramlarına referansla, rejimlerin ne şekilde anlamlandırılabileceğine dair bir perspektif sunacak ve FTKR'nin etkinliği de bu teorik tartışmalardan hareketle değerlendirilecektir. Çalışmanın planıyla ilgili olaraksa; ilk olarak FTKR'nin amacı, işlevi ve yapısına dair bir değerlendirme sunulacak; bu kısmın ardından uluslararası rejim kavramına dair teorik bir tartışma paylaşılacaktır. Daha sonraki kısımda, FTKR'nin gerek uluslararası güvenliğe sunduğu katkılar, gerekse başarısını kısıtlayan faktörlere temas edilecektir. En son kısımda ise FTKR'nin füze ve kitle imha silahlarından kaynaklanan tehdidi önlemeyi amaçlayan bir inisiyatif olarak etkinliğini arttırması için atılması gerekli olan adımlarla ilgili bir perspektif sunulacaktır.

\section{FTKR'nin Amacı, İșlevi ve Yapısı}

1987 y1lında G-7 ülkelerinin inisiyatifinde hayata geçen FTKR, bünyesinde üye olarak barındırdığ 35 devletle, uluslararası güvenlik alanında önemli girişimlerden biridir. Soğuk Savaş'ın kapanış evresinde füze sistemlerinin yayılmasından duyulan kaygıların giderilmesi amaciyla 
Füze Teknolojisi Kontrol Rejimi:

ABD Merkezli Hegemonik Bir Yapıdan Normatif Bir Yapıya Geçişin Önemi

hayata geçen bu inisiyatif, gerek füze gerekse füze üretiminde gereken fiziki ve teknolojik unsurların ihracatını sınırlandırmak şeklinde bir işleve sahiptir. FTKR 1987 yılında hayata ilk geçtiğinde, nükleer silahlardan duyulan endişe nedeniyle, bu silahları taşıma kapasitesine sahip füze sistemlerinin yayılmasını önlemeyi amaçlanmıştır. 1992'de ise kimyasal ve biyolojik silahlar gibi farklı kitle imha silahlarını da kapsamına alan bu oluşum, bu silahları hedeflerine ulaştırma yeteneğine sahip vasıtaların da kontrolünü gerçekleştirmeye başlamıştır. 2003 yılına gelindiğinde ise denetim mekanizması daha da güçlendirilerek, insanlı hava aracı hariç, FTKR listesinde yer almasa da füze geliştirme işlemlerinde kullanılabilecek yeni imkân ve kabiliyetlerin takibinin yapılması kararlaştırılmıştır. ${ }^{5} \mathrm{Bu}$ bağlamda, kitle imha silahı sevk edebilecek füzelerin üretiminde yalnızca "somut" risk ve tehditler değil, "muhtemel" risk ve tehditler de izleme kapsamına alınmıştır.

Risk ve tehditlere FTKR çatısı altında cevap üretilirken, iki ayn kategoriden oluşan "Ekipman, Yazılım ve Teknoloji Belgesi" adlı metin yol gösterici bir işlev görmektedir. Bu belgenin ilk kategorisi (Kategori-1); balistik füzeler, uzaya firlatma araçları ve insansız hava araçları (IHA) gibi unsurların $300 \mathrm{~km}$ mesafenin ötesinde yol kat edebilen ve aynı zamanda $500 \mathrm{~kg}$ ağırlığın üzerinde yük taşıyabilen türlerinin ihracatını yasaklamayı öngörmektedir. FTKR metnine göre İHA sınıfına dâhil araçlar kategorisinde, seyir füze sistemleri, hedef ve keşif uçağı da yer almaktadır. Füze kategorisi kapsamında FTKR, balistik füzeler özelinde olduğu gibi, seyir füzelerini ve bu füzelerin üretiminde gereken teknolojinin yayılmasını da önlemeyi amaçlamaktadır. Kategori-1 kapsamında ayrıca atmosfere yeniden giriş araçları, roket motorları, seyrü-sefer ve güdüm sistemleri ve savaş başlığı mekanizmaları gibi ana alt sistemler de yasak kapsamındadır. Öte yandan 7 Ocak 1993 tarihinden geçerli olmak üzere hayata geçirilen değişikliklerle, taşıma kapasitesi ve menzilden bağımsız olarak, kitle

5 "The MTCR: Staying Relevant 25 Years On”, Strategic Comments, 2012, Cilt: 18, No: 2, 1-3, s. 1. 
828

Güvenlik Stratejileri

Cilt: 16

Sayı: 36

imha silahı gönderebilecek bütün araçların ihracatı (insanlı hava aracı hariç) denetim altına alınmıştır. ${ }^{6}$

Kategori-2'de ise, Kategori-1'de yer almayan füze sistemleri, uzay firlatma araçları ve İHA gibi unsurların $300 \mathrm{~km}$ mesafeye eşit ya da bu mesafeyi aşabilen türleri kapsanmaktadır. Bununla birlikte, kitle imha silahı taşıyabilen araçların dışında kalan, ama onların imalatında veya etkinliklerinin artırılmasında kullanılabilecek muhtelif ekipman, araç-gereç, malzeme ve teknolojik unsur da bu kategori kapsamında değerlendirilmektedir. FTKR, Kategori-1 kapsamındaki unsurlarla ilgili güçlü bir kontrol mekanizması özelliği taşımakta olup, Kategori-2 kapsamındaki unsurlar için devletlere daha fazla esneklik tanımaktadır.

FTKR'nin yapısıyla ile ilgili vurgulanması gereken önemli bir husus, bu düzenlemenin resmi olmayan bir mutabakat üzerine temellendiğidir. Bunun anlamı, FTKR'nin ihlaller karşısında kurumsal olarak ve bütünlüklü bir şekilde ülkeleri hedef alamadığı ve üyelerin ihlal durumunda kendi inisiyatifleri ile yaptırım uygulamasına başvurduklarıdır. Örnekleriyle ilerleyen paraflarda açıklanacağı gibi, FTKR'nin taşıyıcı aktörü olan ABD'nin yaptırım gücü bu organizasyonun işlerliğinde önemli bir yere sahiptir. ABD, 1976 tarihli Silah İhracat1 Kontrol Yasas1 ve 1979 tarihli İhracat İdaresi Kanun'undan yaralanarak FTKR kurallarını ihlali durumunda yaptırım kartına başvurabilmektedir. ${ }^{7}$ Ayrıca 1 Şubat 2010'da geçerlilik kazanan "Yabancı Şahıslar Tarafından Füze Ekipmanı veya Teknolojisi Transferi" adlı yasa maddesi de FTKR kurallarının ihlali durumunda ABD'ye yaptırım uygulama imkânı tanımaktadır. ${ }^{8}$ Öte yandan içerdiği kaidelerle FTKR, Birleşmiş Milletler Güvenlik Konseyi'nin (BMGK) füze

${ }^{6}$ The MTCR, "Guidlines for Sensitive Missile-Relevant Transfers", https://mtcr.info/ guidelines-for-sensitive-missile-relevant-transfers/ (Erişim Tarihi: 22. 07. 2020).

${ }^{7}$ Wyn Q. Bowen, The Politics of Ballistic Missile Nonproliferation, 2000, Basingstoke: Macmillan, s. 41.

8 "22 U.S.C. 2797b- Transfers of missile equipment or technology by foreign persons", https://www.govinfo.gov/app/details/USCODE-2009-title22/USCODE-2009-title22chap39-subchapVII-sec2797b/summary (Erişim Tarihi: 24.07.2020). 
Füze Teknolojisi Kontrol Rejimi:

ABD Merkezli Hegemonik Bir Yapıdan Normatif Bir Yapıya Geçişin Önemi

teknolojisi ihracatı alanında uyguladığı yaptırımlarda dayanak noktası işlevi görmektedir. Diğer taraftan, BMGK tasarılarında kabul edilen maddeler FTKR'nin öngördügü limitlerin ötesine geçebilmektedir. Örneğin Kuzey Kore özelinde 2087 sayılı BMGK kararı, bu ülkeye füze üretiminde gerekli ürünlerin tam teşekküllü bir şekilde ihracatını yasaklamıştır. FTKR kolektif bir yaptırım mekanizmasına sahip olmadığı için, BMGK vasıtasıyla alınan kararlar daha kapsamlı ve etkili bir cezai nitelik taşımaktadır. ${ }^{9}$

ABD'nin baskın pozisyonda bulunduğu FTKR dâhilinde üyelerin yerine getirmesi gereken temel sorumluluk, FTKR'nin öngördüğü normatif çerçeveye uygun davranarak, füze teknolojisinin yayılması konusunda gerekli tedbirleri almalarıdır. Normatif çerçeve vurgusunun önemi, FTKR'nin yasal bir mahiyete sahip olmaması, fakat buna rağmen füze teknolojisinin yayılmasını önleme hususunda içerdiği prensiplerle, yerleşik bir teamül haline getirilmeye çalışılmasıdır. Üye ülkelerden beklenen, FTKR prensiplerine uyumlu davranmaları ve ihraç edilmesi sakıncalı unsurlar konusunda iş birliği içinde çalışarak FTKR kaidelerinin korunmasını sağlamalarıdır.

FTKR resmi bir sekreterliğe sahip olmayıp, Paris şehri, kurumun "İrtibat Noktası" olarak işlev görür. Üye ülkelerin Fransa nezdindeki büyükelçilik temsilcilerinin katıldığ 1 İrtibat Noktası Zirveleri’nde iştirakçi ülkeler arasında bilgi alışverişinde bulunulur. Üye ülkeleri bir araya getiren temel inisiyatif ise, bazı istisnalar olsa da senelik bazda düzenlenen Genel Kurul toplantılarıdır. Bu toplantılarda FTKR'nin işleyişini ilgilendiren gerekli konular ele alınır. Genel Kurul'a, Bilgi Değişimi, İzin ve Uygulama Uzmanları Toplantısı ve Teknik Uzmanlar Toplantısı gibi alt-gruplar halinde icra edilen toplantılar eşlik eder. Genel Kurul toplantılarında gündeme alınan konuların, Paris'te gerçekleştirilen "Güçlendirilmiş İrtibat Noktası" toplantıları ile takibi

\footnotetext{
${ }^{9}$ Leonard S. Spector, "The Missile Technology Control Regime and Shifting Proliferation Challenges", April 2018, Arms Control Today, https://www.armscontrol.org/act/201804/features/missile-technology-control-regime-shifting-proliferation-challenges (Erişim Tarihi: 26.07.2020).
}

\section{9}

Güvenlik Stratejileri

Cilt: 16

Say1: 36 

gündeme geldiğinde ise, bu konu oy birliği prensibi üzerinden sonuca bağlanır. Her ne kadar FTKR iştirakçi ülkelere sahip bir oluşum olarak kurumsal yapısında üyelik olgusunu esas alsa da kural ve yasakların FTKR haricindeki ülkeler gibi, FTKR dâhilindeki ülkelere dönük olarak da uygulanması öngörülür. Böylece, üyelerin yasak kapsamına giren teknolojik unsurların kendi aralarında ithalat veya ihracatını gerçekleştirmelerine de müsaade edilmemektedir. ${ }^{10}$

FTKR'nin temel hedefi, kapsama alanına giren riskleri "sınırlandırmaktır". "Sinırlandırmak" fiiliyle vurgulanmak istenen, füze teknolojisine sahip aktörlerin zaten mevcut olduğu bilgisi 1şığında, FTKR'nin bu unsurların "sınırlı" sayıda ülkenin elinde kalmasını sağlamaya çalışmasıdır. Bu bağlamda FTKR'nin amacı, riski “ortadan kaldırmak" değil, riskin "yayılmasını önlemektir". FTKR özü itibariyle bir "önleme rejiminin" bileşeni olarak uluslararası güvenliğe katkı sunmayı amaçlamaktadır. ${ }^{11}$

\section{Uluslararası Rejim Kavramına Dair Teorik Yaklaşımlar}

FTKR'nin içinde bulunduğu ve bu çalışmada "füze tehdidini önleme rejimi" olarak adlandırılan teşebbüs gibi birçok farklı uluslararası rejim, dünya sorunlarının müşterek bir şekilde çözüm bulunmasına

\footnotetext{
${ }^{10}$ Missile Technology Control Regime, https://mtcr.info/frequently-asked-questionsfaqs/ (Erişim Tarihi: 23.07.2020).

${ }^{11} \mathrm{Bu}$ bölümdeki teknik bilgiler FTKR'nin sitesinden alınmıştır. Missile Technology Control Regime, https://mtcr.info/ (Erişim Tarihi: 05. 01. 2020). Konu ile ilgili ek kaynaklar için bkz; Wyn Q. Bowen, a.g.e., s. 37-42; Dinshaw Mistry, Containing Missile Proliferation: Strategic Technology, Security Regimes, and International Cooperation in Arms Control, University of Washington Press, Seattle, 2003, s. 46-50; Dinshaw Mistry ve Mark Smith, "Negotiating Multilateral Instruments Against Missile Proliferation", International Negotiation, 2005, Ciltt: 10, 425-451, s. 426-435; James J. Wirtz (Ed.), Weapons of Mass Destruction: An Encyclopedia of Worldwide Policy, Technology, and History (Volume II: Nuclear Weapons), Santa Barbara: ABC Clio, 2005, s. 219-220, 454-455; Richard H. Speier, K. Scott McMahon ve George Nacouzi, "Penaid Nonproliferation: Hindering the Spread of Countermeasures Against Ballistic Missile Defense", Santa Monica, CA: The RAND Corporation, 2014, s. 15-22.
} 
Füze Teknolojisi Kontrol Rejimi:

ABD Merkezli Hegemonik Bir Yapıdan Normatif Bir Yapıya Geçişin Önemi

imkân tanıyan mekanizmalardır. Uluslararası rejimler içerdikleri norm ve kurallarla silahlanma, çevre kirliliği, göç, küresel ısınma ve insan hakları gibi farklı sorun ve konuların ele alınmasını sağlarlar. Özellikle Soğuk Savaş’tan sonra küresel yönetişim (global governance) eksenli çabaların artmasına paralel olarak uluslararası rejimler ciddi bir genişleme kaydetmiş ve "çevre, ticaret, nakliye, havacılık, internet, kitle imha silahları, konvansiyonel silahlar, insan hakları" gibi konularda uluslararası aktörlerin iş birliği içinde çalışmalarına katkı sunmaya başlamışlardır. ${ }^{12}$

Uluslararas1 rejimlerin niteliksel ve niceliksel olarak genişlemesinde ise ABD liderliğinde tanzim edilen uluslararası liberal düzen kilit bir işlev görmüştür. Bu düzenin insani, ekonomik ve güvenlik alanlarında ihtiva ettiği norm ve ilkeler, uluslararası rejimlerin işleyişi ve küresel yönetişimin icrasında belirleyici roller oynamışlardır. İnsani güvenlik nasıl sağlanır, ekonomik kalkınma nasıl gerçekleştirilir, kitle imha silahlarının yayılması nasıl engellenir gibi sorulara cevap aranırken, demokrasi, insan hakları, serbest piyasa ekonomisi, kolektif güvenlik anlayışı ve hukuksal normlar, baz alınan kriterler olmuştur. Uluslararası liberalizmin sunduğu normatif zeminde devletler ve hükümet dış1 aktörler (NGO) sağlık, iklim değişikliği, çatışmasızlık, insani gelişim, göç ve kitle imha silahlarının yayılması gibi birçok farklı soruna çözüm ararken, müşterek çabaların nasıl kurumsallaştığını anlama noktasında uluslararası rejim kavramına sıklıkla başvurulmuştur.

Uluslararası İlişkiler disiplininde, kolektif çabaların "uluslararası rejim" kavramı üzerinden irdelenmesine John Ruggie öncülük etmiştir. ${ }^{13}$ 1975 y1lında yayınlanan bir makalesinde bu kavrama yer veren Ruggie, uluslararas1 rejimleri, bir grup devlet tarafindan kabul edilen kurallar,

12 Constance Duncombe ve Tim Dunne, "After Liberal World Order", International Affairs, 2018, Cilt: 94, No: 1, 25-42, s. 32-33.

${ }^{13}$ Robert Keohane. After Hegemony: World Political Economy Cooperation and Discord, Princeton University Press, New Jersey, 1984, s. 57. John Ruggie'nin uluslararası rejim kavramına ilk kez yer verdiği çalışma için bkz; John Gerard Ruggie, "International Responses to Technology: Concepts and Trends", International Organization, 1975, Cilt: 29, No: 3, 557-583. 
832

Güvenlik Stratejileri

Cilt: 16

Sayı: 36

düzenlemeler, planlar, örgütsel çabalar ve finansal taahhütler seti olarak tanımlamıştır. ${ }^{14}$ Daha sonra Ruggie, nükleer materyallerin kontrolü rejimi ve uluslararası para rejimi gibi inisiyatifler üzerinden uluslararası rejimleri örneklendirmeye çalışmıştır. ${ }^{15}$ Aktörlerin müşterek sorunlara çözüm bulmak amacıyla çabalarını ortaklaştırmaları ve kurumsallaşma yönünde adımlar atmaları, kaçınılmaz olarak örgütleşmeye gidildiği intibaına zemin sunmaktadır. Fakat rejim ve örgüt birbirlerinden farklı kavramlardır. Uluslararası örgütler, uluslararası rejimlerin işleyişinde kolaylaştırıcı, uygulayıcı ya da operasyonel açılardan çeşitli roller oynayabilseler $\mathrm{de}^{16}$ muhtevas1 itibariyle rejimler "konu bazlı" (issue-based) olarak dünya sorunlarına hangi girişimler, yöntemler ve araçlarla çözüm arandığını gösteren mekanizmalardır. Örgütler ise bir "sorun" ya da "konuya" eğilebildikleri gibi (örn. Dünya Ticaret Örgütü), kapsama alanları çok daha geniş olabilir (örn. Birleşmiş Milletler).

$\mathrm{Bu}$ itibarla uluslararası rejimlere dair bir anlamlandırma denemesinde, kavramsal açıdan odak noktası, bir kurum ve/veya örgüt üzerine değil, konu ve/veya sorun üzerine sabitlenmelidir. Örneğin NPT, nükleer silahsızlanma rejiminin temelini oluştursa da Nükleer (ya da Londra) Tedarikçiler Grubu'nun prensipleri, Uluslararas1 Atom Enerjisi Ajansı'nın tüzüğü, bölgesel ölçekte nükleer silahların kontrolüne yönelik Tlatelolco Antlaşması ve Rarotonga Antlaşması'nın maddeleri gibi destekleyici unsurlar da bu rejimin birer bileşenidir. ${ }^{17} \mathrm{Bu}$ çalışmanın konusu olan FTKR ise "füze tehdidini önleme rejiminin" önemli bir sütunu olsa da HCOC, Wassenaar Düzenlemesi ve Kitle İmha Silahlarının Yayılmasına Karşı Güvenlik İnisiyatifi gibi girişimler de söz konusu rejimi desteklemektedir. ${ }^{18} \mathrm{Bu}$ ve benzeri örnekler, uluslararası

${ }^{14}$ John Gerard Ruggie, a.g.m., s. 570.

${ }^{15}$ John Gerard Ruggie, a.g.m., s. 571.

${ }^{16}$ John Gerard Ruggie, a.g.m., s. 574.

${ }^{17}$ Andreas Hasenclever vd. Theories of International Regimes, Cambridge University Press, Cambridge, 2004, s. 10.

18 Sibylle Bauer, "The Export Control Regimes", SIPRI Yearbook 2016: Armaments, Disarmament and International Security, Oxford: Oxford University Press, 2016, 758-767. 
Füze Teknolojisi Kontrol Rejimi:

ABD Merkezli Hegemonik Bir Yapıdan Normatif Bir Yapıya Geçişin Önemi

rejimlerin niçin belirli kurumlarla özdeş anılmaması ve bunun yerine, "konu bazlı" olarak değerlendirilmesi gerektiğini açıklamaktadır.

Uluslararası rejimlerin amaç ve işlevi mercek altına alındığında, içinde barındırdıkları kural, norm ve pratiklerle rejimler, aktörlerin beklenti ve davranışlarını öngörülebilirlik ekseninde şekillendirmeyi amaçlarlar. Literatürde sıkça atıf yapılan Stephen Krasner'ın tanımlamasına göre rejimler, "aktörlerin beklentilerinin örtüştüğü, açık ya da örtülü bir şekilde ifade edilen ilke, norm, kural ve karar alma prosedürleri setidir". ${ }^{19}$ İlkeler; olgu, nedensellik ve doğruluk üzerine temellenen inançlar iken; normlar, hak ve yükümlülükler ekseninde tanımlanan davranış standartlarıdır. Kurallar ise yönerge ve yasaklardan mütevellit olup, karar alma prosedürleri, kolektif eylemin icra ve uygulamasında temel pratikler olarak tanımlanır. ${ }^{20}$ Uluslararası rejimlerin teorik bir bağlamda tanımlaması yapıldığında, Robert Keohane'nin aktardığı gibi, bu mekanizmaların dünya siyasetinde "ara değişken" olarak görev ifa ettikleri söylenebilir. Örneğin bu ara değişken, güç dağılımı ile uluslararası aktörlerin davranışları arasındaki ilişkide bir faktör olarak yer alır. ${ }^{21}$ Devletler odak noktasına alındığında, uluslararası sistemde rejimlerin etkinliği, belirsizliğin üretebileceği istikrarsızlıkları engelleme ve devletler arası ilişkilerde güç siyasetinin hafifletilmesini sağlama kabiliyetleri ile doğru orantılıdır.

Rejimler, uluslararası sistemde kolektif faydanın sağlanmasında önemli roller oynayabilseler de işlevselliklerini değerlendirme noktasında farklı bakış açıları görülebilmektedir. Neorealist bir açıdan bakıldığında, otoritesizliğin ürettiği daimi güvenlik endişeleri, aktörlerin rejimler dâhilinde iş birliği denemelerini sekteye uğratacak bir engel olarak ortaya çıkar. Zira aktörler, mutlak değil nispi kazanç peşindedirler; bu nedenle bir rejime iştirak ederlerse ne elde ettiklerini, diğer aktörlere

19 Stephen D. Krasner, "Structural Causes and Regime Consequences: Regimes as Intervening Variables", Stephen D. Krasner (ed.), International Regimes, Cornell University Press, Ithaca, 1983, 1-21, s. 2.

${ }^{20}$ Stephen D. Krasner, a.g.m., s. 2.

${ }^{21}$ Robert Keohane, a.g.e., s. 64. 
834

Güvenlik Stratejileri

Cilt: 16

Say1: 36

kıyasla hesaplarlar. Bir aktör kendisinden daha fazla kazanç elde edilmesi durumunda nispi olarak gerileme yaşayacağından, rejimlere riayet etmekten vazgeçebilir; ya da rejime dâhil olsa da ilerleyen dönemde rejim kurallarını ihlal etme yolunu seçebilir. ${ }^{22} \mathrm{Bu}$ minvalde hile endişesi, uluslararası rejim ve kurumların etkinliğini zayıflatan önemli bir risktir. ${ }^{23}$ Rejimlerle ilişkili olarak etkileşim maliyetini azaltma, şeffaflık sağlama ve iş birliği ağını genişletme gibi olumlu çıkarsamalar yapılabilse de rejimlerin içerdiği kurallar manzumesinin belirli aktörlerin çıkarlarını gözetecek şekilde tanzim edilmesi muhtemeldir. ${ }^{24}$ Neorealist (ya da Yapısalc1 Realist) teorisyen John Mearsheimer'a göre, uluslararas1 oluşumlar büyük güçlerin tasarladıkları kurallar manzumesinden ibarettir; büyük güçler uluslararası kurumlar dâhilinde belirlenen kurallara, bu kurallar kendi çıkarlarına uygun ise riayet ederler. Kurallar büyük gücün çıkarlarına hizmet etmediği anlarda ise bu aktörler ya kurallara uymamayı ya da kuralları değiştirmeyi denerler. ${ }^{25}$ Bir nevi, uluslararası düzenin işleyişini mümkün kılan kural ve normlar, hâkim güçlerin çıkarlarını yansıtan bir mahiyet taşımalıdır; aksi takdirde, büyük güçler kuralları işlevsizleştirecek adımlar atmaktan sakınmayacaklardır.

Kurumsalcı bir perspektiften bakıldığında ise rejimler fayda optimizasyonu açısından işlevsel mekanizmalar olduklarından, aktörler rejimlerin çatısı altında olmayı ve kurallara riayet etmeyi sıklıkla tercih ederler. Liberal Kurumsalcı yaklaşım bu hususun altını çizerken, rejimlerin dünya siyasetini tanzim etmede fonksiyonel boyutuna vurgu yapmaktadır. Örneğin rejimler, belirsizliği azaltarak ve meşru davranışın ne olduğuyla ilgili bürokrat ve siyasetçilerin politika alanlarını çerçeveleyerek, beklentilere dair öngörülebilirlik sağlarlar. Ayrıca

${ }^{22}$ Shah M., Tarzi, "International Regimes and International Relations Theory: Search for Synthesis", International Studies, 2003, Cilt: 40, No: 1, 23-39, s. 26.

${ }^{23}$ John J. Mearsheimer, "The False Promise of International Institutions", International Security, 1994, Cilt: 19, No: 3, 5-49.

${ }^{24} \mathrm{~S}$. Javed Maswood, The South in International Economic Regimes: Whose Globalization?, Palgrave Macmillan, Basingstoke, 2006, s. 52.

${ }^{25}$ John J. Mearsheimer, "Bound to Fail: The Rise and Fall of the Liberal International Order', International Security, 2019, Cilt: 43, No: 4, 7-50, s. 9. 
Füze Teknolojisi Kontrol Rejimi:

ABD Merkezli Hegemonik Bir Yapıdan Normatif Bir Yapıya Geçişin Önemi

rejimler güçlü yaptırım mekanizmalarından yoksun olabilseler de aktörler ihlal durumlarında itibarlarının zarar görebileceğini göz önüne alarak, rejim kaidelerine uyma konusunda siklıkla hassasiyet gösterirler. ${ }^{26} \mathrm{Bu}$ durum büyük güçler için dahi geçerli olup, bu yöndeki hassasiyet şu şekilde bir nedensellik üzerinden açıklanmaktadır: devletler, yalnız bir konuyla değil, birçok farklı konuyla aynı anda ilgilenmek zorundadırlar; bu nedenle, bir konuda hilekarlığa ya da sorumsuzluğa başvurulması durumunda, bunun farklı konu başlıklarını da etkilemesi ve devletlerin önüne beklenmedik maliyetler çıkarması kuvvetle muhtemeldir. ${ }^{27}$ Devletler, çıkarlarına hizmet etmediklerine inansalar dahi kurallara riayet etmeyi sıklıkla tercih ederler; zira, tekrardan vurgulanırsa, bir alanda kuralsızlık göstermek, belirli bir networkte bulunan diğer rejimlerin de işleyişini olumsuz etkiler. ${ }^{28}$ Bu bağlamda, söz konusu bir devlet baskın bir güç olsa dahi, orta ve uzun vadeli çıkarları gereği rejim kurallarına riayet etmeyi seçebilir.

Zayıf devletler için ise uluslararası rejimler, kendi kapasiteleri ile etki etmelerinin mümkün olmadığı güçlü devletleri dizginlemeye yarar. Kural ve kaideler rejimlerin bütün katılımcıları için geçerli olacağından, güç kapasitesi sınırlı devletler çıkarlarını korumak için rejimlerin sağladığı işlevselliğe ihtiyaç duyabilir. ${ }^{29}$ Nitekim, büyük güçler yönlendirici aktörler olsalar da ilişkilerin kurumsallaştığı bir düzende zayıf aktörler de ifade imkânı bulur ve hegemonik gücü etkileme şansı yakalar. ${ }^{30}$ Kurumsalcılığ 1 esas alan faydacı bir bakış açısından güçlü ve zayıf aktörler, farklı nedenlerle olsa da, uluslararası rejimlerin işlevselliğinden çıkarları gereği istifade ederler.

Devletlerin uluslararası rejimlerle olan ilişkilerini maddi kazançkayıp dengesi üzerinden analiz eden yaklaşımlarda normatif unsurlar

\footnotetext{
${ }^{26}$ Robert Keohane ve Joseph S. Nye. "Review: Power and Interdependence Revisited", International Organization, 1987, Cilt: 41, No: 4, 725-753, s. 744.

${ }^{27}$ Robert Keohane, a.g.e., s. 97.

${ }^{28}$ Robert Keohane, a.g.e., s. 104.

${ }^{29}$ Stephen D. Krasner, "Transforming International Regimes", s. 120.

${ }^{30}$ G. John Ikenberry, Liberal Leviathan. Princeton University Press, Princeton, 2011, s. 38-39.
}

\section{5}

Güvenlik Stratejileri

Cilt: 16

Say1: 36 

aktörlerin fayda maksimizasyonu ile açıklanamayacak davranışlarda bulunabildiği; bunun için faydacı analizler yerine, düşünsel (ideasyonel) unsurları esas alan, norm-eksenli analizlere ihtiyaç duyulduğunu vurgulamaktadır. ${ }^{31} \mathrm{Bu}$ bağlamda aktörler, uluslararası rejimlerin norm ve kurallarına riayet etmeyi kabul ettiklerinde, bu yönde bir kararn, söz konusu aktörlerin kimliksel özelliklerine ve nasıl bir normatif yapıda hareket ettiklerine bakılmadan anlaşılması güçtür. ${ }^{32}$ Realistlerin iddia ettiklerinin aksine normatif yap1 önceden verili kabul edilmemelidir; zira uluslararası yapılar, farklı normatif değerleri bünyelerinde barındırabilmekte olup, sistemsel değişiklikler gerçekleştiği zaman (savaşlardan sonra olduğu gibi) bu değerler, aktör davranışını şekillendirmede önemli roller oynarlar. ${ }^{33} \mathrm{Bu}$ minvalde, sosyalizasyon süreci her zaman mümkündür ve dünya siyaset sahnesinde değişim ve dönüşüm olanak dâhilindedir. $\mathrm{Bu}$ mercekten bakıldığında, gerekli sosyalizasyon sürecinden geçmiş aktörler yalnızca çıkar/fayda çerçevesinde değerlendirilemeyecek davranışlar sergilerler. Dolayısıyla, uluslararas1 rejimlerin norm ve kurallarına uyulduğunda, bunun, aktörlerin içselleştirdiği değerler sistemiyle ilintili olması kuvvetle muhtemeldir. Bir aktör, örneğin, deniz kirliliği ya da iklim değişikliği gibi konuları ele alan rejimlere katılırken, bu yönde bir kararın faydacılıkla ilintili olmaktan ziyade, ekolojik konulara hassasiyetten kaynaklı kimliksel özelliklerle ilintili olması kuvvetle muhtemeldir.

Uluslararası rejimler devletler arası ilişkilerin tanziminde çıkar, fayda ya da norm eksenli olarak farklı kavramsal merceklerden açıklanabilmektedir. Ortaya konulan farklı perspektiflere rağmen,

${ }^{31}$ Martha Finnemore ve Kathryn Sikkink. "International Norm Dynamics and Political Change", International Organization, 1998, Cilt: 52, No: 4, 887-917.

${ }^{32}$ Peter J. Katzenstein (ed.), The Culture of National Security: Norms and Identity in World Politics, Columbia University Press, New York, 1996.

${ }^{33}$ Peter J. Katzenstein, "Coping with Terrorism: Norms and Internal Security in Germany and Japan", Judith Goldstein and Robert O. Keohane (ed.), Ideas and Foreign Policy: Beliefs, Institutions, and Political Change, Cornell University Press, Ithaca, 1993, 265-295, s. 266. 
Füze Teknolojisi Kontrol Rejimi:

ABD Merkezli Hegemonik Bir Yapıdan Normatif Bir Yapıya Geçişin Önemi

uluslararası rejimlerin devletler arası ilişkilerde düzenleyici mekanizmalar olarak dünya siyasetinde önemli bir konuma sahip oldukları muhakkaktır.

\section{FTKR'nin Uluslararası Güvenliğe Katkıları}

Füze tehdidini önleme alanındaki rejimin önemli bir sütunu olan FTKR, 30 yılı aşkın bir süredir uluslararası güvenlik alanında önde gelen inisiyatiflerden biri olmuştur. Faaliyet alanı itibariyle FTKR, gerek kitle imha silahlarını taşıyabilecek araçların, gerekse bu araçların üretimi için gereken ekipman ve teknolojinin yayılmasını yavaşlatmaktan sorumludur. 1987 yılından bu yana üye sayısını düzenli olarak arttıran bu oluşum, üye ülkelerin füze teknolojisi ihracatında norm uyumu sağlamasını ve yasal ve idari standartlarını FTKR kaidelerine göre düzenlemelerini sağlamıştır. FTKR'nin daha da göze çarpan başarısı, üye olmayan ülkeleri dahi kendi normlarına uygun davranmaya teşvik edebilmesidir. Örneğin İsrail, Çin, Romanya ve Slovakya her ne kadar FTKR'ye resmi olarak katılmamışlarsa da bu oluşumun kaidelerine riayet etmeyi taahhüt etmişlerdir. ${ }^{34}$ FTKR'nin uluslararası güvenliğe sunduğu katkılar, BM Güvenlik Konseyi'nin tasarılarında dahi bu oluşumun kaidelerinin yer bulmasında ve FTKR'nin dönem başkanlığını yürüten devletlerin, Tasarı 1540 özelinde olduğu gibi, ilgili BM toplantılarına katılarak füze tehdidi konusunda farkındalık yaratma teşebbüslerinde görülebilmektedir. ${ }^{35}$ Diğer taraftan, üyeler arasında gerçekleştirilen zirvelerde, kitle imha silahı taşıyabilecek vasıtaların yayılması konusunda düzenli istişareler gerçekleştirilerek, tehditlerin güncelliği ve böylece uluslararası güvenliğin korunması konusunda farkındalık yaratılmaktadır. Örneğin, en sonuncusu 2019 yılında Yeni Zelanda'da gerçekleşen Genel Kurul Toplantısı'nda, uzaya uydu firlatma sistemlerinin üretimi için

34 “The Missile Technology Control Regime (MTCR)", 08 January 2018, The Nuclear Threat Initiative, https://www.nti.org/learn/treaties-and-regimes/missile-technologycontrol-regime-mtcr/ (Erişim Tarihi: 08. 03. 2020).

${ }^{35}$ LDWO, "Report by the MTCR Chair: MTCR Chair addressed HCOC Plenary", 22 June 2016, https://mtcr.info/report-by-the-mtcr-chair-mtcr-chair-addressed-hcoc-plenary/ (Erişim Tarihi: 16. 01.2020). 
838

Güvenlik Stratejileri

Cilt: 16

Sayı: 36 geliştirilen yeni stratejilere dikkat edilmesi, maddi olmayan teknoloji transferleri nedeniyle ortaya çıkan risklerin mercek altına alınması ve FTKR kapsamına alınmamış tehdit içerikli öğelerin denetlenmesi gibi hususlarda fikir birliğine varılmıştır. ${ }^{36}$

FTKR'nin işlevini muhafaza eden bir oluşum olmasında, bünyesine yeni üyeleri katabilme başarısı önemli bir faktördür. Bu kapsamda, Soğuk Savaş sonrası yaşanan jeopolitik kırılma önemli bir imkân teşkil etmiştir. Zira, Doğu Bloku'nun dağılması sonrasında batı kurumlarına dâhil olmak ya da batı ile ilişkilerini güçlendirmek isteyen ülkeler için FTKR'nin kaidelerine uymak, önemli bir ön koşul olarak ortaya konulmuştur. $\mathrm{Bu}$ minvalde Çek Cumhuriyeti ve Polonya gibi Doğu Avrupa ülkeleri FTKR'ye dâhil olmak için balistik füzelerinden arınmışlar ve nihayetinde 1998 yılında bu oluşuma resmi olarak katılmışlardır. ${ }^{37}$ Rusya'nın ardından eski Sovyet coğrafyasının füze sistemleri üretiminde en yetkin ikinci ülkesi olan Ukrayna'nın FTKR'ye dâhil olması ise bir başka olumlu örnektir. Özellikle ABD'nin yoğun çabalarıyla hem kıtalararası balistik füzelerinden hem de nükleer silah envanterinden arınan Ukrayna ${ }^{38}$, FTKR ve NPT gibi oluşumlara katılarak, füze ve nükleer silahsızlanma konularında uluslararası güvenliğe katk1 sunan bir politika izlemiştir.

ABD merkezli batı bloğu, füze tehdidi konusunda sorumlu davranmayan ülkeleri "havuç-sopa" yöntemleriyle FTKR standartlarına uygun davranmaya zorlarken, Sovyetler Birliği'nin dağılmasından sonra ciddi bir füze envanteri, teknolojisi ve bilgi-birikimine sahip olan Rusya, dikkatlerin en fazla yoğunlaştığı ülke olmuştur. Rus/Sovyet

${ }^{36}$ Jeffrey Taylor, "Public Statement from the Plenary Meeting of the Missile Technology Control Regime, Auckland", 11 October 2019, https://mtcr.info/public-statement-fromthe-plenary-meeting-of-the-missile-technology-control-regime-auckland-11-october2019/_(Erişim Tarihi: 08.01.2020).

37 Arms Control Association, "The Missile Technology Control Regime at a Glance", July 2017, https://www.armscontrol.org/factsheets/mtcr (Erişim Tarihi: 15. 02.2020).

${ }^{38}$ Steven Pifer, The Eagle and the Trident: U.S-Ukraine Relations in Turbulent Times, Brookings Institution Press, Washington, D.C, 2017. 
Füze Teknolojisi Kontrol Rejimi:

ABD Merkezli Hegemonik Bir Yapıdan Normatif Bir Yapıya Geçişin Önemi

Glavkosmos SSSR ve Hindistan Uzay Araştırmaları Örgütü arasında henüz Sovyetler Birliği dağılmadan önce, Ocak 1991'de imzalanan bir anlaşma bu bağlamda önemli bir örnektir. Rusya'nın anlaşma gereğince Hindistan'ın uydu firlatma araçları için iki adet yukarı aşama modülü tedarik etmesi planlanmıştır. Fakat bu anlaşma, yalnız Kategori-1 kapsamındaki teçhizat ve teknoloji ihracat yasağını değil, üretim tesisi oluşturulması kuralını da ihlal etmiştir. NPT ve FTKR'ye katılmaktan imtina eden Hindistan'ın niyetlerine şüphe ile yaklaşan $A B D$ ise FTKR'nin ihlali nedeniyle Rus üretici firmalara ve Hindistan Uzay Araştırmaları Örgütü'ne iki yıllık süreyle yaptırım uygulamaya başlamıştır. Öte yandan ABD yetkilileri, Hindistan ve Rusya arasındaki anlaşmanın iptal edilmemesi durumunda, füze sistemleri üretimi konusunda Rus ve ABD şirketleri arasında farklı alanlarda süregelen iş birliğinin risk altına gireceğini aktarmışlardır. ${ }^{39}$

$\mathrm{Bu}$ süreçte ikinci bir kriz ise Rusya'nın Libya'ya roket motorlarının performansı için gerekli olan kimyasal maddeleri tedarik etmesi sırasında yaşanmıştır. Kaddafi yönetiminin eylemlerinden kaygı duyan ABD, Kategori-2 kapsamına giren bu satış nedeniyle belirli Rus şirketlerini yaptııı kapsamına almıştır. Hindistan ve Libya nedeniyle yaşanan krizler Rusya'yı ABD ile müzakereye sevk etmiş ve nihayetinde 19 Kasım 1993'de hayata geçirilen 'Rusya Federasyonu'nun Füze Silahlarının Üretiminde Kullanılan Ekipman, Malzeme ve Teknolojilerin Kontrolüne Dair Prosedürler" adlı bir yönergenin kabul edilmesiyle, Rusya'nın yasal düzenlemelerini FTKR standartlarına uyumlu hale getirmesi kararlaştırılmıştır. Bu süreçte, gerek ABD ve IMF'nin Rusya'ya sağladığ 1 ekonomik yardımlar, gerekse ABD yaptırımlarının Rusya'nın uzay sektörünü olumsuz etkilemesi, Rusya'yı uzlaşmaya sevk eden nedenler olmuştur. Yaşanan bu gelişmeler Rusya'nın 1995'te FTKR'ye dâhil olmasının altyapısını hazırlamıştır. ${ }^{40}$

39 Bilgiler için bkz: Charles C. Petersen, "Moscow, Washington and the Missile Technology Control Regime", Contemporary Security Policy, 1995, Cilt: 16, No: 2, 44-71.

${ }^{40}$ Charles C. Petersen, a.g.m; Joseph Cirincione vd., Deadly Arsenals: Nuclear, Biological, and Chemical Threats, Carnegie Endowment for International Peace, Washington D.C, 
840

Güvenlik Stratejileri

Cilt: 16

Sayı: 36

Füze, ekipman ve teknoloji ihracatı konusunda dönemsel olarak yaşanan anlaşmazlıklar FTKR'ye üye ülkeler arasında da görülmüştür. Örneğin, Fransız Arianespace adlı bir şirketin roket motorlarının üretiminde kullanılan teknolojiyi Brezilya'ya ihracını öngören 1989 tarihli anlaşma ABD'nin muhalefetiyle karşılaşmıştır. Brezilya, 1960'larda ABD'nin desteğiyle başlattığ üretimiyle devam etmiş, 1979 yılına gelindiğinde ise sivil uzay alanındaki deneyiminden yararlanarak, uydular ve bu uyduları yörüngeye gönderecek VLS-1 roketlerini geliştirmeye başlamıştır. Müteakiben, özel şirketlerin de katılımıyla balistik füze çalışmalarına yönelen Brezilya, bu çabalar doğrultusunda iş birliği kurabileceği yabacı ortaklar bulmaya başlamıştır. Brezilyalı mühendislerin Scud-B füzelerinin menzilini arttırmak isteyen Irak'a katkıda bulunmaları ve Brezilya'nın Libya ile füze teknolojisi alanında iş birliği içinde olduğundan şüphelenilmesi, bu dönemde öne çıkan gelişmeler olmuştur. Fakat Brezilya'nın 1970'lerin sonunda başlayan ve 1980'lerin sonuna kadar devam eden bu ilişkileri, FTKR'nin kural ve normlarının ihlali anlamına geldiği için, FTKR Brezilya'yı teknoloji ihracatı alanında yasaklanan ülkeler arasına almıştır. ABD Ticaret Bakanlığı ise Brezilya'nın balistik füze programını "kayg1 verici" kategorisine dâhil etmiştir. ${ }^{41}$

Irak ve Libya ile olan yakın ilişkileri ve sivil uzay faaliyetleri için üretildiği iddia edilen roketlerin askerî unsurlara dönüştürülmesi, Brezilya'yı özellikle ABD nezdinde güvenilmez bir ülke kılmış ve bu nedenle Fransa ve Brezilya arasındaki anlaşmanın önlenmesine çalışılmıştır. Nitekim ABD, Fransa'nın roket motorlarının üretiminde kullandığ1 teknolojiyi Brezilya'ya ihraç etmesi durumunda, bu teknolojinin balistik füze üretiminde kullanılmasından ve bunların üçüncü

2005, s. 318-319.

41 Matias Spektor, "The Evolution of Brazil's Nuclear Intentions", 2016, The Nonproliferation Review, Cilt: 23, No: 5-6, 635-652; Matias Spektor, "The Long View: How Argentina and Brazil Stepped Back from a Nuclear Race", 2015, Americas Quarterly, No: 57, s. 1; Scott D. Tollefson, Brazil, the United States, and the Missile Technology Control Regime, Naval Postgraduate School, California, March 1990, s. 17-18. 
Füze Teknolojisi Kontrol Rejimi:

ABD Merkezli Hegemonik Bir Yapıdan Normatif Bir Yapıya Geçişin Önemi

tarafların eline geçmesinden kaygı duymuştur. Bu kaygıdan hareketle ABD (ve Büyük Britanya), Fransa'nın FTKR kaidelerini esnek yorumlayarak norm dışına çıktığını iddia etmiştir. Son kertede, özellikle ABD'nin baskısıyla Fransız Arianespace şirketi 1991 senesinde Brezilya'ya dönük teklifini geri çekmiştir. ${ }^{42} 1994$ y1lında ise Brezilya balistik füze programını terk etmiş ve ABD'nin baskı ve çabalarıla 1995 'te FTKR'ye üye olmuştur. 1995'ten sonra Brezilya'nın uzay sektörü FTKR üyelerinden yapılan teknoloji transferi ile ilerlemiştir. ${ }^{43}$

FTKR'nin kaidelerinin korunmasında, siyasi iktidarların kendi ülke şirketlerini denetim altında tutmaları bir diğer önemli faktör olmuştur. Örneğin 1990 senesinde Büyük Britanya hükümeti, İngiliz Havacılık Şirketi (BAE) ve Arab British Dynamics adlı bir diğer şirket arasında yürütülen ortak çalışmaların Büyük Britanya'nın FTKR kaidelerine uyma taahhüdünü ihlal ettiği uyarısında bulunmuştur. Bu uyarının arkasında, Arab British Dynamics'in Mısır ordusu için Scud-B füzeleri üretmesi etkili olmuştur. Büyük Britanya hükümetinin uyarısı sonrasında BAE, uzman personelini Mısır'dan çekerek ortak çalışma grubundaki iştirakini sonlandırmıştır. ${ }^{44}$

Füze teknolojisinin yayılmasını engelleme konusunda sergilenen müşterek çabalar, FTKR'ye üye ülkeler arasında sağlanan norm uyumu sayesinde meyve vermiştir. FTKR'nin dışında kalan ülkeler ise füze teknolojisi transferi konusunda norm dışına çıktıkları anlarda, FTKR'nin kısıtlamalarına maruz kalmışlar ve izledikleri politikadan vazgeçmek zorunda kalmışladır. Bu kapsamda, örneğin, Arjantin, Mısır ve Irak'ın müşterek olarak yürüttükleri Condor II balistik füze programından vazgeçmeleri, FTKR'nin önemli bir başarısıdır. Bu başarının arkasında

42 Deborah A. Ozga, a.g.m., 75-76; Keith Payne, "The Missile Technology Control Regime-European Involvement and Compliance Issues 2", 15 July 1998, Commission to Assess the Ballistic Missile Threat to the United States, Appendix III: Unclassified Working Papers, https://fas.org/irp/threat/missile/rumsfeld/pt2_payne.htm (Erişim Tarihi: 10.02.2020).

${ }^{43}$ Allen Chong, "Revisiting the Missile Technology Control Regime: Fostering a New Norm for Ballistic Missiles", Canadian Foreign Policy, 1999, Cilt: 7, No: 2, 107-126, s. 108.

${ }^{44}$ Deborah A. Ozga, a.g.m., s. 77. 
842

Güvenlik Stratejileri

Cilt: 16

Sayı: 36

yatan temel etken, FTKR'nin 1987 yılında hayata geçmesinden sonra Condor-II projesine iştirak eden Fransız, İtalyan ve Alman şirketlerin faaliyetlerini durdurmak zorunda kalmalarıdır. ${ }^{45} \mathrm{Bu}$ bağlamda, bu üç ülkenin FTKR'ye üyeliği, ulusal şirketlerin yabancı projelerde iştirakçi olmalarını kısıtlayan bir sonuç doğurmuş ve nihai kertede dışarıdan tedarik edilen know-how ve teknoloji desteği kesilince, Condor-II programı tamamlanamadan sonlanmıştır.

Gerek kitle imha silahları gerekse füze sistemleri geliştirme konularında başlıca kaygı yaratan ülkelerden biri de Güney Afrika Cumhuriyeti olmuştur. Bu ülke 1991 yılında NPT'ye üye olmuşsa da füze geliştirme programına devam etmiştir. İsrail'in desteğiyle yerli bir füze programı yürüten Güney Afrika, FTKR'nin ambargolarına rağmen orta menzilli balistik füze test edebilecek noktaya gelebilmiştir. Fakat Güney Afrika bu programı daha ileri düzeye taşıyarak hem etkili ve hem de maliyet bakımından ulaşılabilir bir uydu firlatma sistemine sahip olmak isteyince, FTKR'nin teknoloji ihracatı alanında uyguladığ1 engellerle karşılaşmışıtır. Güney Afrika esas olarak ticari kullanıma yönelik bir uydu firlatma altyapısına sahip olmak istemişse de FTKR'nin teknoloji ihracatı bakımından devreye soktuğu engeller, bu çabalara mâni olmuştur. FTKR'nin yasaklan, Soğuk Savaş'ın bitişiyle düzelen güvenlik ortamı ve ABD'nin siyasi ve ekonomik baskısıyla birleşince, Güney Afrika füze geliştirme politikasını revize etmiştir. ABD'li yetkililer 1992-1993 yıllarında Güney Afrikalı muhatapları ile yaptıkları görüşmelerde, ticari amaçla da olsa, Güney Afrika'nın yabancı teknolojiye ulaşmadan istediği roket programına sahip olmayacağını ileri sürmüşlerdir. Güney Afrikalı karar alıc1lar uygulanan bask1 politikası nedeniyle, 1993 senesinde ülkelerinin FTKR'nin füze ihracatı mevzuatını kabul ettiğini deklare etmişlerdir. 1995'te ise Güney Afrika'nın FTKR'ye tam üyeliği gerçekleşmiştir. ${ }^{46}$

45 "Rumblings Precede 25th Missile-Control Meeting", Strategic Comments, 2011, Cilt: 17 , No: $3,1-3$, s. 1.

${ }^{46}$ Detaylar için bkz; Dinshaw Mistry, a.g.e., s. 84-88. 
Füze Teknolojisi Kontrol Rejimi:

ABD Merkezli Hegemonik Bir Yapıdan Normatif Bir Yapıya Geçişin Önemi

Uzak Doğu'daki stratejik rekabet ortamında da FTKR belirli başarılar kaydetmiştir. İlerleyen satırlarda da değinileceği gibi, her ne kadar FTKR'nin bir üyesi olmasa da Güney Kore 2012 senesine kadar bu oluşumun kaidelerine uygun hareket etmiştir. ABD ile yürüttüğü temaslar çerçevesinde Güney Kore, 1979-1997 yılları arasında balistik füze menzilini 300 km'nin altında tutmuştur. Böylece FTKR'nin kuruluş y1lı olan 1987 baz alındığında, 2012'ye kadar 25 yıllık bir süreyle Güney Kore'nin balistik füze programı FKTR sınırlarında tutulmuştur. Fakat aşağıda değinileceği gibi, 2012 yılı itibariyle FTKR'nin 300 km/500 kg limiti Güney Kore tarafından aşılmıştır.

Farklı örnek hadiselerden görülebileceği gibi, 1987 y1lında hayata geçirilen, 1992 revize edilen ve 2003'te kontrol kapsamı genişletilen FTKR, uluslararası güvenlik alanında önemli işlevler görmüş ve "füze tehdidini önleme rejiminin" önemli bir sütunu olduğunu kanıtlamıștır. Öte yandan, ayrı bir parantez açılacak olursa, söz konusu önleme rejiminin, Wassenaar Düzenlemesi gibi diğer kritik inisiyatiflerle desteklendiği de gözlerden kaçırılmamalıdır. Wassenaar Düzenlemesi özelinde vurgulanırsa, füze sistemleri üretiminde gerekli malzeme ve teknolojik unsurun yayılmasını önlemede bu inisiyatif FTKR'den bile daha etkin kontroller gerçekleştirebilmektedir. Örneğin, ihracat yasağını uygulama amacına matuf ekipman ve dokümantasyon kontrolü yapabilen, nokta atışı denetlemeler uygulayabilen ve gerektiğinde sevkiyat gemilerini alıkoyabilen bu girişim, "füze tehdidini önleme rejiminin" temel bileşenlerinden biri olduğunu göstermiştir. ${ }^{47} \mathrm{Keza}$, kitle imha silahları ve bu silahları sevk edebilecek araçların kontrolsüz yayılmasını dizginlemede HCOC ilkeleri de güven arttırıcı bir işlev görmektedir. Balistik füze programları, uzay firlatma araçları, sevk platformları ile ilgili bilgi ve açıklık sağlamak ve ön bilgilendirme yöntemiyle devletler arası ilişkilere öngörülebilirlik kazandırmak, HCOC'nin uluslararası güvenliğe katkıları

\footnotetext{
47 "Best Practices for Effective Export Control Enforcement", https://www.wassenaar.org/ app/uploads/2019/consolidated/Best-Practices-for-Effective-Export-Control-Enforcement.pdf (Erişim Tarihi: 21. 07.2020); Bauer, a.g.m., s. 766.
}

\section{3}

Güvenlik Stratejileri

Cilt: 16

Say1: 36 
844

Güvenlik Stratejileri

Cilt: 16

Say1: 36

arasındadır. ${ }^{48}$ Bir bütünlük içinde ele alınırsa, Wassenaar Düzenlemesi, HCOC ve FTKR'nin birbirlerini besleyen düzenlemeler oldukları ortaya çıkmaktadır.

FTKR özelinde bakıldığında ise ülkelerin kendi teknolojik ve bilgi birikimleriyle uzun menzilli füze sistemleri geliştirmelerinin zorluğu dikkate alındığında, FTKR'nin füze ihracatı, ekipman ve teknoloji transferinde engelleyici bir mekanizma olarak önemli bir görev gördüğü açıtır. Aşağıda temas edileceği üzere, ilerleyen y1llarda FTKR kaidelerine uymayan ülke sayısında bir artış olmuşsa da en azından ilk 20 yılında bu inisiyatif uluslararası güvenliğe fayda sağlayan bir işlev görmüştür.

\section{FTKR'nin Başarısını Kısıtlayan Etkenler}

FTKR'nin olumlu katkılarına rağmen, bu oluşumun belirli noksan tarafları olduğu ve sıklıkla eleştirilere tabi kaldığı da gözlerden kaçırılmamalıdır. FTKR'ye dönük yöneltilen tenkitlerde özellikle meşruiyet eksenli itirazlar öne çıkmakta olup, bu konuda en fazla göze çarpan eleştirilerden biri, bu oluşumun adil olmayan bir düzeni hâkim kılmaya yaradığıdır. Bu görüş doğrultusunda, gelişmiş ülkelerin FTKR aracılığıyla ellerindeki teknolojik üstünlüğü muhafaza ettikleri ve gelişmekte olan ülkelerin, ihracat kısitlamaları yoluyla füze sistemleri geliştirmelerini engellemeye çalıştıkları dile getirilmektedir. Böylece "teknolojik emperyalizm" olarak tanımlanabilecek bir düzen sürdürülerek, hiyerarşik bir ilişkiler bütünü hâkim k1lınmaktadır. ${ }^{49}$ Bunun ulusal güvenlikle ilgili belirgin bir sonucu ise gelişmekte olan ülkelerin Kategori2 kapsamına girecek olan ikincil öneme haiz unsurlara dahi erişiminin engellenmesi ve böylece caydırıcı bir füze envanterine sahip olma imkânlarının ortadan kaldırılmasıdır. Benzer bir gerekçe ekonomik nedenler üzerinden de zikredilmiş ve FTKR nedeniyle gelişmekte olan ülkelerin uzay sektörünün önüne set çekildiği iddia edilmiştir. ${ }^{50}$

48 "Text of the HCOC", https://www.hcoc.at/?tab=what_is_hcoc\&page=text_of the_hcoc (Erişim Tarihi: 22. 07. 2020).

${ }^{49}$ Allen Chong, a.g.m., s. 109.

${ }^{50}$ Deborah A. Ozga, a.g.m., s. 68. 
Füze Teknolojisi Kontrol Rejimi:

ABD Merkezli Hegemonik Bir Yapıdan Normatif Bir Yapıya Geçişin Önemi

Bununla birlikte, FTKR önemli sayıda ülkenin füze programı geliştirmesini engelleyebilmişse de belirli istisnalar söz konusu olmuştur. Kuralları ihlal etme pahasına ve yaptırım baskısına rağmen, gerek Kategori-1 gerekse Kategori-2 kapsamında değerlendirilebilecek ihracatlar gerçekleştirilmiştir. Söz konusu ülkelerin başında, FTKR hükümlerine uyduğunu iddia eden ama Pakistan, İran, Suudi Arabistan ve Kuzey Kore gibi ülkelere önemli tedariklerde bulunmuş olan Çin gelmektedir. Çin, Pakistan'a 700 ve 1500 km menzilli Shaheen 1 ve Shaheen 2 katı yakıt balistik füzelerinin üretimi için ekipman transferinde bulunmuş, $300 \mathrm{~km}$ menzilli ve $800 \mathrm{~kg}$ yük taşıyabilen M-11 kısa menzilli balistik füzeleri satmış ve Kuzey Kore'nin bu ülkeye sıvı yakıt füzeleri ve teknolojisi ihraç etmesine yardımcı olmuştur. İran'a ise seyir füzesi üretimi için teknoloji transferinde bulunmuş; keza Shahab füzelerinin üretiminde Çin'in teknolojik katkısı rol oynamıştır. Orta Doğu'da Çin'in füze tedariki alanında ilişki kurduğu bir diğer aktör Suudi Arabistan olmuş ve 1987'den başlamak üzere Çin bu ülkeye DF-3A ve DF-21 orta menzilli balistik füzeler satmıştır. Kuzey Kore'ye ise Çin, SCUD ve Nodong füzelerinin operasyonel hale gelmesinde teknik destek sunmuş ve çok kademeli Taepodong füzesinin üretimine katkıda bulunmuştur. ${ }^{51}$

$\mathrm{Bu}$ ilişkiler, beklentilere uygun şeklide, ABD'nin tepkisini çekmiştir. Örneğin, M-11 füzelerinin Pakistan'a tedarikinin FKTR kaidelerini ihlal ettiği gerekçesiyle 1993 'te Clinton yönetimi Çin'e yaptırım uygulamaya başlamıştır. $\mathrm{Bu}$ geliş̧me sonrasında Çin, FTKR'nin kurallarına uyacağını taahhüt etmişse ve Clinton yönetimi 1994 'te yaptırımları kaldırmışsa da ${ }^{52}$ Çin, Güney Doğu Asya'da Hindistan

\footnotetext{
${ }^{51}$ Richard D. Fisher, China's Military Modernization: Building for Regional and Global Reach. Praeger Security International, Connecticut, 2008, s. 48-53; Sebastien Roblin, "Saudi Arabia Already Has a Ballistic Missile Arsenal Courtesy of China-With a Little Help from the CIA", The National Interest, 22 September 2018, https://nationalinterest.org/ blog/buzz/saudi-arabia-already-has-ballistic-missile-arsenal-courtesy-china\%E2\%80\%94little-help-cia-31772 (Erişim Tarihi: 22. 07.2020).

${ }_{52}$ Missile Defense Project, "DF-11 (Dong Feng-11 / M-11 / CSS-7)", Missile Threat, Center for Strategic and International Studies, 29 January 2018, https://missilethreat. csis.org/missile/dong-feng-11/ (Erişim Tarihi: 16.02.2020).
}

\section{5}

Güvenlik Stratejileri

Cilt: 16

Sayı: 36 
846

Güvenlik Stratejileri

Cilt: 16

Sayı: 36

karşısında önemli bir müttefik olarak gördüğü Pakistan'la olan füze üretimi odaklı ilişkisini (Shaheen füzeleri özelinde vurgulandığ gibi) devam ettirmiştir.

Öte yandan FTKR, Kuzey Kore'nin dış yardımla füze teknolojisi geliştirmesinin önüne geçemediği gibi, bu ülkenin füze ve füze teknolojisi ihracatı gerçekleștirmesini de engelleyememiștir. $\mathrm{Bu}$ kapsamda en çarpıcı örneklerden biri Kuzey Kore-İran ilişkisidir. İki ülke arasındaki iş birliği İran'ın muhatabından, Kuzey Kore'nin Hwasong 5 ve Hwasong 6 olarak adlandırdığı Scud B ve Scud C füzeleri almasıyla başlamıştır. 1980'lerde alından bu füzeler İran tarafindan Shahab 1 ve Shahab 2 olarak adlandırılmıştır. 1990'larda daha da gelişen ilişkilerle birlikte İran, Kuzey Kore'den Nodong 1 (Shahab 3) füzesini, 2000'lerde ise Nodong 2 (Shahab $3 \mathrm{M}$ ) füzesini satın almıştır. ${ }^{53}$ İran haricinde Kuzey Kore; Pakistan, Yemen, Suriye ve Misır gibi ülkelere Scud ve Nodong füzeleri satmış ve ayrıca Pakistan ve İran ile ortak füze geliştirme programları içinde yer almıştır. ${ }^{54}$

Yukarıdaki hadiselerin gösterdiği gibi FTKR, yapılan ihlalleri belirli durumlarda tespit edip engelleyebilse de belirli durumlarda etkisiz kalabilmektedir. FKTR'nin etkisini sınırlandıran kritik bir faktör ise, bu oluşumun taşıyıcı gücü olmasına rağmen ABD'nin de belirli zamanlarda FTKR kurallarını esnetmesidir. ABD'nin Güney Kore ile 2012 yılında imzaladığı ve iki taraf arasında 1979 ve 1997 tarihli mutabakatları ikame eden bir anlaşma, bu duruma bir örnektir. Güney Kore ve ABD arasında 1979 yılında imzalanan bir anlaşma ile Güney Kore'nin, geliştirmek istediği füzelerin $180 \mathrm{~km}$ menzille sınırlandırılması şartıyla, ABD'nin füze teknolojisinden yararlanmasına onay verilmiştir. 1995-1997 yılları arasında yapılan müzakereler sonucunda varılan yeni bir mutabakatla ise Güney Kore'nin balistik füze menzilini FTKR'nin belirlediği $300 \mathrm{~km}$ limitine kadar çıkarması hususunda

${ }^{53}$ Nelson E. Hansen, "North Korean-Iranian Cooperation in Ballistic Missile Development", Jungmin Kang (ed.), Assessment of the Nuclear Programs of Iran and North Korea, Dordrecht: Springer, 2013, 115-127, s.116

${ }^{54}$ Nelson E. Hansen, a. g. m., s. 26. 
Füze Teknolojisi Kontrol Rejimi:

ABD Merkezli Hegemonik Bir Yapıdan Normatif Bir Yapıya Geçişin Önemi

anlaşılmıştır. ${ }^{55}$ Fakat 2012 yılına gelindiğinde, Güney Kore'nin Kuzey Kore'den duyduğu tehdidin dozundaki artış neticesinde $\mathrm{ABD}$, müttefikinin $800 \mathrm{~km}$ menzile sahip ve $500 \mathrm{~kg}$ yük taşıyabilecek balistik füzeler ve ayrıca 2,5 tona kadar yük taşıyabilecek İHA'lar geliştirmesine onay vermiştir. ${ }^{56}$ Güney Kore ile varılan bu anlaşma, hem menzil (300 km) hem de yük $(500 \mathrm{~kg})$ bakımından FTKR kaidelerini açıkça ihlal eden bir nitelik taşımıştır. 2017 senesinde ise 1979 tarihli anlaşmanın 2012 tarihli anlaşmanın da ötesine geçilerek, daha da esnetilecek şekilde revize edilmesi konusunda taraflar mutabakata varmışlardır. ${ }^{57}$

İhlal içerikli benzer bir hadise ABD'nin İsrail'e tedarik etmek üzere üretimine katkı sunduğu Arrow füze savunma sisteminin önleyici füzeleri özelinde yaşanmıştır. Kategori-1 kapsamına giren bu füzelerin ABD'de üretilip İsrail'e ihraç edilmesine FTKR kaideleri engel çıkardığı için, yeni bir formül bulunmuştur. Bu formül gereği, Arrow füzelerinin ihtiyaç duyduğu parçaların \%51'lik kısmının üretimi ABD'de Boeing tarafından gerçekleştirilmiş ve füze unsurları ayrı parçalar halinde İsrail'e ihraç edilmiştir. İsrail'de ise bu parçalar bir araya getirilmiş; kalan \%49'luk kısım ise İsrail Uçak Sanayi tarafından üretilerek, Arrow sistemlerinin imalatı tamamlanmıştır. 2003 senesinde ise Arrow füzelerinin test edilmesi için İsrail'den ABD'ye gönderilmesi sürecinde yeni bir sorun ortaya çıkarmıştır. Zira ABD'deki test işleminden sonra Arrow'un tekrardan İsrail'e gönderilmesinin, FTKR kurallarını ihlal edeceği görülmüş̧ür. Ortaya çıan yasal komplikasyonu aşmak için, Arrow'un test sirasında mülkiyetinin İsrail'in elinde bulunması

\footnotetext{
55 Daniel Pinkston, "The New South Korean Missile Guidelines and Future Prospects for Regional Stability", International Crisis Group, 25 October 2012, https://www.crisisgroup. org/asia/north-east-asia/korean-peninsula/new-south-korean-missile-guidelines-and-futureprospects-regional-stability (Erişim Tarihi: 20.07.2020).

56 Roehrig Terence, Japan, South Korea, and the United States Nuclear Umbrella: Deterrence After the Cold War, Columbia University Press, New York, 2017, s. 142.

57 Reuters, "U.S., South Korea Agree to Revise Missile Treaty in Face of North Korean Threats", 2 September 2017, https://www.reuters.com/article/us-northkoreamissiles/u-s-south-korea-agree-to-revise-missile-treaty-in-face-of-north-koreanthreats-idUSKCN1BD034 (Erişim Tarihi: 22.02.20).
}

\section{7}

Güvenlik Stratejileri

Cilt: 16

Say1: 36 
848

Güvenlik

Stratejileri

Cilt: 16

Sayı: 36

yönünde bir düzenleme yapılmıştır. Böylece İsrail'in test için kendi füzelerini bir başka ülke toprağında bulundurduğu şeklinde bir formül yaratılmaya çalışılmıştır. ${ }^{58}$

ABD'nin FTKR kaidelerini ihlal ettiği bir diğer örnek, Büyük Britanya'ya Trident D5 sınıfına ait denizaltından atılan balistik füze satmasıdır. Bu hadisede ilginç olan nokta, Büyük Britanya'nın öncelikle Trident C4 füzesi talep etmesine rağmen, Ronald Reagan'ın başkanlığa gelmesiyle birlikte ABD'nin Trident D5 füzesi satmayı muhatabına bizzat kendisinin teklif etmesidir. ABD'nin Trident D5 füzelerine geçiş yaptığını vurgulayan Reagan, kızışan Soğuk Savaş ortamı nedeniyle Büyük Britanya'nın elindeki Polaris füzelerini Trident C4 füzeleri yerine, menzil ve isabetlilik bakımından daha yetkin, fakat aynı zamanda daha pahalı, bir sistem olan Trident D5 ile ikame etmesini önermiştir. ${ }^{59}$ 1994'de Büyük Britanya'nın kullanımına giren Trident D5, hem menzil $(2000-12.000 \mathrm{~km})$ hem de yük $(2800 \mathrm{~km})$ bakımından FTKR limitlerinin çok ötesinde bir sistem özelliği taşımıştır. ${ }^{60}$ ABD'nin sergilediği bazı dolaylı eylemler de FTKR kaidelerinin aşınması sonucunu doğurmuştur. Örneğin, Çin'in $1800 \mathrm{~km}$ menzile sahip DF-21 füzelerinin Suudi Arabistan'a satışı sırasında ABD bilgi sahibi olmuş ve hatta 2007 yılında CIA yetkilileri DF-21'lerin nükleer başlık taşımadıklarından emin olmak için bu füzelere dönük bir kontrol gerçekleştirmişlerdir. ${ }^{61}$

İsrail, Güney Kore, Suudi Arabistan ve Büyük Britanya'nın içinde yer aldığ 1 bu örnek hadiseler, FTKR'nin kurallarına riayet edilmesi konusunda ABD'nin eklektik politikalar izleyebildiğini göstermektedir. ABD ve Büyük Britanya'nın FTKR'nin birer üyesi olduğu dikkate

58 Detaylar için bkz; Sarah Chankin-Gould ve Ivan Oelrich, "Double-Edged Shield", Bulletin of the Atomic Scientists, 2005, Cilt: 61, No: 3, 36-41, s. 39.

59 Suzanne Doyle, "A Foregone Conclusion? The United States, Britain and the Trident D5 Agreement", Journal of Strategic Studies, 2017, Cilt: 40, No: 6, 867-894.

${ }^{60}$ Missile Defense Project. "Trident D-5", Missile Threat, Center for Strategic and International Studies, 15 June 2018, https://missilethreat.csis.org/missile/trident/ (Erişim Tarihi: 29.09.2020).

${ }^{61}$ Sebastien Roblin, a.g.m. 
Füze Teknolojisi Kontrol Rejimi:

ABD Merkezli Hegemonik Bir Yapıdan Normatif Bir Yapıya Geçişin Önemi

alındığında, bu oluşuma üye ülkelerin dahi ihlallere imza atabildiğinin görülmesi, FTKR'nin üye olmayan ülkeleri kısitlamasını daha da zorlaştırmaktadır. Güney Kore, Suudi Arabistan ve İsrail ise FTKR'nin üyesi değillerse de ABD'nin bu ülkelere gösterdiği müsamaha, diğer ülkeler nezdinde eşitsizlik algısının pekişmesine neden olmaktadır. $\mathrm{Bu}$ algının yerleşmesinde, yukarıda ismi geçen ülkelerin ABD ile savunma alanında yakın ilişki içinde olmaları önemli bir etkendir. Bu durum doğal olarak, FTKR kapsamında imtiyazlı ülke kategorisine dâhil olanlar ve olmayanlar ayrımına zemin sunmaktadır. FTKR'nin Çin ve Pakistan gibi ülkeleri bünyesine katamaması ve İran ve Kuzey Kore gibi ülkelerin balistik füze programlarını engelleyememesinde, muhatap ülkelere "eşit mesafe" prensibi üzerinden yaklaşılamaması önemli bir handikaptır.

FTKR'nin etkinliğini güçlendirmek için eşitlik prensibini hâkim k1lmak ne kadar önemliyse, yeni teknik güncellemeleri hayata geçirmek de bir o kadar önemlidir. Bu bağlamda ifade edilmelidir ki, 30 yılı aşkın bir süredir uygulamada olan FTKR'nin etkinliğini özellikle İHA'lar ile ilgili anakronik hale gelmiş teknik düzenlemeler sınırlamaktadır. FTKR'ye üye ülkelerin İHA'ların transferi konusunda, aynı füze sistemlerine dönük olduğu gibi, FTKR kaidelerine uygun davranmaları beklenmektedir. Bunun anlamı, kitle imha silahı taşıyabilecek, $300 \mathrm{~km}$ 'den uzun menzile sahip ve ayn zamanda $500 \mathrm{~kg}$ 'dan fazla faydalı yük taşıyabilen İHA'ların yayılmasının önlenmesidir. Fakat FTKR'nin norm ve kurallarının belirlendiği 1980'ler ile mevcut konjonktür arasında, İHA'ların kullanım amaçları bakımından ciddi farklılıklar bulunmaktadır ve bu farklılıklar, FTKR'nin teknolojik gelişmelere paralel olarak güncellenmesini gerekli kılmaktadır. 1980'li yıllarda seyir füzelerinin bir alt grubu sınıfında değerlendirilen İHA'lar, tek yönlü bir şekilde kullanılan unsurlar olarak ya hedefleme ya da kısamenzilli gözetleme şeklinde işlevler görmüşlerdir. Ancak günümüzde kullanılan İHA'lar (örneğin Çin'in CH-4, İsrail'in Heron TP veya ABD'nin MQ-9 Reaper adlı İHA'ları), uçaklara benzer şekilde, uzun süre havada kalarak keşif ve gözetleme görevleri görmekte ya da hassas güdümlü füzeleri hedefe yönlendirme veya kendi taşıdıkları 
Eray ALIM

850

Güvenlik Stratejileri

Cilt: 16

Say1: 36

füzeleri ateşleme yetenekleriyle çok daha kapsamlı işlevler yerine getirebilmektedirler. ${ }^{62}$

İHA'lar yalnız askerî değil, sivil açıdan da sıklıkla kullanılan unsurlar haline gelmişlerdir. Örneğin doğal afet, tarım, enerji, telekomünikasyon, denizcilik ve meteoroloji gibi muhtelif alanlarda İHA'lardan istifade edilmektedir. Bu unsurların sivil ve askerî hayatın önemli birer ögesi haline gelmesi, İHA'ların FTKR kapsamında yeni bir değerlendirmeye tabi tutulmasını gerektirmektedir. Sivil hayattaki kullanımıyla artık füze sınıfinda değerlendirilmesi gittikçe zorlaşan İHA'lar, FTKR'nin etkinliğini sekteye uğratan bir rol oynamaktadır. Zira amaçları arasında yer almasına rağmen FTKR'nin muhtelif amaçla kullanılabilecek İHA'ların yayılmasını engelleyememesi, bu oluşumun etkinliği ve itibarı açısından olumsuz bir durumdur. $\mathrm{Bu}$ sorunu gidermek için, "füze-İHA" ayrımını esas alan yeni düzenlemelerin yapılması zaruridir.

ABD, FTKR'nin kurallarına binaen sınırlı sayıda ülkeye İHA ihracat1 gerçekleştirmekteyse de FTKR'nin resmi bir üyesi olmayan Çin ve İsrail, çok daha aktif bir şekilde gelişmiş IHA'larını ihraç etmektedirler. İHA'lar devlet harici grupların eline geçerse intihar saldırıları gibi terör eylemleri meydana gelebilir kaygısından hareketle ABD'nin izlediği ihtiyatlı politika, yakın stratejik ilişki içinde olduğu ülkelere dahi İHA ihracatı gerçekleştirmesini zorlaştırmaktadır. ${ }^{63}$ FTKR'ye üye olmayan Çin ise bu durumdan yararlanarak, Mısır, Ürdün, Suudi Arabistan ve Birleşik Arap Emirlikleri gibi ülkelere İHA ihracatı gerçekleştirmiş ve halihazırda büyümekte olan İHA pazarında önemli bir paya sahip olmuştur. ${ }^{64} \mathrm{Bu}$ hususlar bir bütünlük içinde ele alındığında,

${ }^{62}$ Michael C. Horowitz, "Drones Aren't Missiles, So Don't Regulate Them Like They Are", the Bullettin, https://thebulletin.org/2017/06/drones-arent-missiles-so-dont-regulatethem-like-they-are/ (Erişim Tarihi: 10. 01. 2020).

${ }^{63}$ Arthur Herman, "The Treaty Behind China's Drone Edge", 8 July 2019, The Wall Street Journal, https://www.wsj.com/articles/the-treaty-behind-chinas-drone-edge-11562626340 (Erişim Tarihi: 12. 02. 2020).

${ }^{64}$ Elisa Catalano Ewers, vd., "Drone Proliferation Policy Choices for the Trump 
Füze Teknolojisi Kontrol Rejimi:

ABD Merkezli Hegemonik Bir Yapıdan Normatif Bir Yapıya Geçişin Önemi

İHA ve füze arasındaki kavramsal karışıklığı gidermek ve İHA'ları FTKR kapsamından çıkarmak, bu girişim çerçevesinde ihtiyaç duyulan önemli bir reformdur. ${ }^{65}$

FTKR'nin ilgilenmesi gereken bir diğer konu ise çifte kullanımlı teknoloji ve bilgiye ulaşımın neden olduğu risklerdir. Nitekim İHA'ların yaygınlaşması da esas itibariyle bu durumun bir sonucudur. İHA'larda kullanılan ve çok küçük ebatlarda üretilen "yüksek megapiksel kameralar, uzun ömürlü lityum piller, yüksek hassasiyete sahip GPS üniteleri ve yetkin bir otomatik pilot için gereken yerleşik sensörler ve yüksek hızlı işlemciler" akıllı telefon endüstrisinin birer ürünüdür. ${ }^{66}$ Teknolojinin yayılmasinın yan tesiri ise artan risk ve tehditlerdir. FTKR kapsamında yer alan silah sistemlerinin üretiminin getirdiği kolaylık sayesinde, yalnız devlet değil, devlet harici aktörler olan Hamas, Hizbullah, IȘíD ve İslami Cihad gibi oluşumlar dahi İHA'lara ulaşabilmektedir. ${ }^{67}$ Sivil ve askerî alanın her ikisinde de kullanılabilecek unsurların yaygınlaşması nedeniyle devletler, yapay zekâ, gelişmiş bilgi işlem teknolojisi, robotik otomasyon, katmanlı üretim veya 3D baskı gibi alanlarında teknoloji ihracatının denetimini sıkılaştırmaktadırlar. ${ }^{68}$ Örneğin füze sistemlerinin muhtelif parçalarının imalatında Katmanlı Üretim (Additive Manufacturing) yöntemiyle önemli sonuçlar alınabilmektedir. NASA'nın 2013'te paylaştığı bilgiye göre, Katmanlı Üretim teknolojisinden yararlanılarak roket için gerekli olan motor enjektörü üretilebilmiştir. ${ }^{69}$ Raytheon firmasının verdiği bilgiye göre ise füze parçalarının \%80'inin

Administration”, Center for a New American Security, June 2017, s. 11.

${ }^{65}$ Michael Horowitz, a.g.m.; Arthur Herman, a.g.m.

${ }^{66}$ Gregory D. Koblentz, "Emerging Technologies and the Future of CBRN Terrorism", The Washington Quarterly, 2020, Cilt: 43, No: 2, 177-196, s. 179.

${ }^{67}$ Gregory D. Koblentz, a.g.m., s. 179.

68 U.S. Government Publishing Office, "Proposed Rules", Federal Register, 19 November 2018, Cilt. 83, No. 223, 58201-58202.

${ }^{69}$ Kolja Brockmann ve Robert Kelley, "The Challenge of Emerging Technologies to Nonproliferation Efforts”, SIPRI, April 2018, s. 12. 
852

Güvenlik Stratejileri

Cilt: 16

Sayı: 36

Katmanlı Üretim teknolojisiyle üretilebildiği noktaya gelinmiş olup, bunun \%100'e ulaşması olanak dâhilindedir. ${ }^{70}$

FTKR zirvelerinde bu gelişmeler masaya yatırılsa da kapsamlı çözümler için nasıl bir politika geliştireceği sorusu hâlâ cevap beklemektedir. ${ }^{71}$ Yaşanmakta olan bu süreçte, ses hızının en az beş katı düzeyine çıkabilen hipersonik füzelerin tedavüle girmesi ise ayrı bir bask1 unsuru olarak FTKR'nin karşısına çıkmaktadır. Rusya, Çin ve ABD'nin başını çektiği büyük güçler, Hipersonik Seyir Füzesi (HCM) ve Hipersonik Yayılma/Süzülme Aracı (HGM) olarak bilinen iki kategorideki hipersonik sistemleri envanterlerine dâhil etmektedirler. Hipersonik silahlarda ön planda yer alan HGV unsurları, hız kabiliyeti kadar, manevra ve keskin isabet yetenekleriyle de öne çıkmaktadır. Burada önemli olan nokta, yüksek isabet gücüne sahip hipersonik araçların, kitle imha silahı taşımak zorunda kalmadan ve FTKR'nin öngördüğü $500 \mathrm{~kg}$ limitinin daha aşağısında kalarak, kritik unsurları hedef alabilmeleridir. Böylece taşıdığ 1 mühimmat tahribat kapasitesi bakımından daha sınırlı olabilse de hız ve hedef gözetme alanındaki keskinliğiyle hipersonik araçlar, stratejik sonuçlar doğurabilecek unsurlardır. $^{72} \mathrm{Bu}$ gelişmeler, FTKR düzenlemelerinde revizyona ihtiyaç duyulduğunu göstermektedir. Bunlar iki başlıkta açıklanabilir. İlk olarak, bütün hipersonik araç kategorisine giren unsurların ihracatının yasaklanmasıdır. İkincisi olarak ise hipersonik araçların üretiminde gereken unsurların denetim altına alınmasıdır. Bu unsurlar şu şekilde özetlenebilir: hipersonik motorlar ve bileşenleri, hipersonik uçuş için gerekli yakıt, malzeme ve termal koruma donanımları, hipersonik uçuş için gerekli sensörler, navigasyon ve iletişim unsurları. ${ }^{73}$

${ }^{70}$ Kolja Brockmann ve Robert Kelley, a.g.m., s. 13.

${ }^{71}$ Taylor, a.g.m.

${ }^{72}$ Hipersonik füzelerle ilgili bir değerlendirme için bkz; Kelly M. Sayler, "Hypersonic weapons: Background and Issues for Congress", 17 March 2020, https://fas.org/sgp/crs/ weapons/R45811.pdf (Erişim Tarihi: 18.04.2020).

${ }^{73}$ Detaylar için bkz; (Özellikle Appendix D) Richard. H. Speier, George Nacouzi, Carrie A. Lee ve Richard M. Moore, "Hypersonic Missile Nonproliferation: Hindering the Spread 
Füze Teknolojisi Kontrol Rejimi:

ABD Merkezli Hegemonik Bir Yapıdan Normatif Bir Yapıya Geçişin Önemi

Gerekli anlarda yeni düzenlemelere imza atılabildiği taktirde, FTKR'nin otuz yılı aşkın süreye rağmen hala güncelliğini koruduğu izlenimi güçlendirilebilecektir. Nitekim 1992 ve 2003 yıllarında yeni düzenlemeler hayata geçirilerek, FTKR'nin bir uluslararası güvenlik inisiyatifi olarak etkinliğini ve güncelliğini korumasına verilen önem gösterilmiştir. Bunun yeni reform adımlarıyla takip edilmesi, FKTR'nin anakronik bir oluşum olmadığı hususunu perçinlemeye yarayacaktır.

\section{FTKR'nin Hegemonik Mahiyeti ve İhtiyaç Duyulan Normatif Yapı}

Olumlu ve noksan taraflaryyla FTKR, uluslararas1 güvenliğe katk1 sunan oluşumların irdelenmesinde önemli bir vaka incelemesidir. Zira bu inceleme üzerinden, ülkeler uluslararası sorunlara çözüm bulmak amaciyla kolektif girişimlerde bulunmaya ve kurumsallaşma yönünde adımlar atmaya karar verirlerken, hangi aktör ve faktörlerin yönlendirici bir rol oynayabileceği sorusuna yanıt üretilebilmektedir. Bu çalışmada ele alındığı üzere FTKR, G-7 ülkelerinden oluşan katılımcıların müşterek çabalarıyla hayata geçmişse de bu oluşumun kuruluş ve işleyişinde $\mathrm{ABD}$ yönlendirici bir etkiye sahip olmuştur. ABD'nin bu sürece öncülük etmesinde ise, bu ülkenin kitle imha silahlarının yayılmasından duyduğu kaygı belirleyici bir rol oynamıştır. Nitekim 1970'lerden itibaren ABD için kitle imha silahlarından neşet eden tehdit, önemli bir güvenlik riski olarak görülmüş ve FTKR'nin kurulma sürecine de bu risk algısı yön vermiştir.

1970'lerin başında, örneğin, roket teknolojisinin hem ticari hem de ulusal güvenlikle ilgili gerekçelere bağlı olarak müttefik ülkelere dahi transferi kısıtlanmıştır. ${ }^{74}$ Bu kaygılara eşgüdümlü şekilde $\mathrm{ABD}$, 1970'lerden itibaren kitle imha silahlarının çoğalmasını önlemek amacıyla, sorumlu davranmadığına inandığı ülkelere dönük sıklıkla yaptırım kartına başvurmuştur. ${ }^{75}$ Adeta, kitle imha silahları ve füze

\footnotetext{
of a New Class of Weapons", Santa Monica, CA: RAND Corporation, 2017.

${ }^{74}$ Dinshaw Mistry, a.g.e., s. 43.

75 Örneğin Pakistan'la ilgili süreç için bkz; Joseph Cirincione vd., a.g.e., s. 243-246.
} 
854

Güvenlik Stratejileri

Cilt: 16

Sayı: 36

teknolojisinin yayılmasını önleme hedefleri eş zamanlı bir şekilde başarılmaya çalışılmıştır. Soğuk Savaş sonrası süreçte de ABD'nin ulusal güvenlik doktrinlerinde, kitle imha silahlarından kaynaklanan risklere dikkat çekilmeye devam edilmiştir. Örneğin Orta Doğu ve Güney Doğu Asya'da, balistik füze ve kitle imha silahlarının yayılması nedeniyle bölge ülkelerinin saldırgan askerî kapasitelerini geliştirdikleri vurgulanmıştır. ABD'nin ise nükleer, kimyasal ve biyolojik silahların ve uzun menzilli füzelerin yayılmasını, müttefik ülkelerle iș birliği halinde çalışarak, önlemeye devam edeceği belirtilmiştir. ${ }^{76}$ FTKR'nin kuruluşu, ABD'nin güvenlik kaygılarıyla birlikte değerlendirildiğinde, Neorealist teorinin önemli bir hipotezi olan, devletlerin uluslararas1 oluşumları kendi (güvenlik) çıkarları doğrultusunda işlevselleştirdikleri görüşünün güçlü bir zemine sahip olduğu görülecektir. ${ }^{77} 1970$ 'lerden beri süregelen bir güvenlik kaygısı ve 1980'lerde bu kaygiyı gidermeyi amaçlayan bir uluslararası oluşumun kuruluşuna öncülük edilmesi, bu iki hadisenin birbirini tamamlayan niteliğini gözler önüne sermektedir.

Bu hususa ilave olarak, FTKR-ABD ilişkisi özelinde Neorealist bir perspektif şu noktaya işaret etmektedir: rejim ve kurumlar kısa vadeli çıkar maksimizasyonunu önlemede yetersizdir ve özellikle büyük güçler, gerekli anlarda menfaatleri doğrultunda rejim kaidelerini ihlal etmekten sakınmazlar. ${ }^{78}$ Neorealist bir mercekten ortaya konulan bu bakış açısının Neoliberal Kurumsalcı bir açıdan çürütülebilmesi için, ABD'nin FTKR kurallarına riayet etme konusuna hassasiyet gösterdiği yönünde bir tespit yapılabilmelidir. Fakat Güney Kore, İsrail, Büyük Britanya ve Suudi Arabistan'ın FTKR normlarının dışına çıkılması anlamına gelen eylemlerine ABD'nin yeşil ışı yakması ve hatta füze teknolojisi desteği sunmas1, ABD'nin FTKR kaidelerine riayet etme konusunda çifte

${ }^{76}$ Principal Deputy Under Secretary of Defense, "Defense Planning Guidance, 19941999", Archives.org. https://www.archives.gov/files/declassification/iscap/pdf/2008003-doc18.pdf, s. 17-18 (Erişim Tarihi: 29.03.2017).

77 John J. Mearsheimer, "A Realist Reply", International Security, 1995, Cilt: 20, No: 1, 82-93, s. 86.

${ }^{78}$ John J. Mearsheimer, "The False Promise of International Institutions". 
Füze Teknolojisi Kontrol Rejimi:

ABD Merkezli Hegemonik Bir Yapıdan Normatif Bir Yapıya Geçişin Önemi

standartlı davranışlara imza atabildiğini göstermektedir. Bu minvalde, her ne kadar Neoliberal Kurumsalcı yaklaşım uluslararası oluşumların kurallarına riayet edilmesinin, büyük güçlerin itibarları açısından önemli olduğunu iddia etse de FTKR'nin baskın gücü olan ABD bu iddiaya tezat davranışlar sergileyebilmekte ve bu oluşumun kurallarını esnetebilmektedir. Brooks ve Wohlforth'un detaylarıyla açıkladığı gibi, itibar kaybı endişesiyle ABD'nin uluslararası oluşumların kaidelerine uygun davrandığı tezi, zayıf bir ampirik temele sahiptir. ${ }^{79}$

Kitle imha silahı sevk edebilecek füze sistemlerinin uluslararası toplumun bütün aktörleri için potansiyel bir tehdit olduğu göz önüne alındığında, Neoliberal Kurumsalcı bir açıdan şu çıkarsama yapılabilir: FTKR'nin kuruluşuna öncülük eden $\mathrm{ABD}$, kolektif faydanın temin edilmesine katk1 sunmuştur. FTKR'nin etkinliğine dönük olaraksa, farklı ülkelerin bu kurumun standartların kabul etmelerinde ABD'nin yaptırım ve baskıları önemli bir rol oynamış ve balistik ve seyir füzesi geliştirmek isteyen birçok ülkenin önüne set çekilebilmiştir. Bununla birlikte, Kurumsalcı bir perspektiften bakıldığında, ${ }^{80}$ FTKR sayesinde, farklı ülke yetkililerinin Teknik Uzmanlar Toplantısı gibi istişare ortamlarında periyodik olarak bir araya gelmelerini sağlayan bürokratik bir mekanizma oluşmuş ve üyeler arasında bir irtibat ve iletişim ağı ihdas edilerek benzer endişelere koordineli cevaplar üretilebilmiştir. Nitekim 1987 'de ilk adımı atılan FTKR'nin yeni tehdit ve risklerle istinaden 1992 ve 2003 yıllarında güncellenmesi, artan üye sayısına rağmen istişare mekanizmasının işlerliği konusunda olumlu işaretler vermektedir. Yukarıda ele alındığı üzere, füze ve İHA ayrımının net bir şekilde yapılması, yeni teknolojilerden kaynaklı risklere etkili cevaplar üretilerek FTKR'nin etkinliğinin daha da üst seviyeye çıkarılması, reform adımlarının atılabildiği göz önüne alındığında, FTKR'nin yetkinlik skalası dâhilindedir.

\footnotetext{
${ }^{79}$ Stephen G. Brooks ve William C. Wohlforth, World Out of Balance: International Relations and the Challenge of American Primacy, Princeton University Press, Princeton, 2008, Chapter 5.

${ }^{80}$ Robert Keohane, a.g.e.
} 
856

Güvenlik Stratejileri

Cilt: 16

Say1: 36

Resmin diğer tarafina bakıldığında ise daha farklı bir tablo ortaya çıkmaktadır. FTKR öncelikle, isminden de anlaşılacağ gibi, kontrol mekanizması işlevi gören bir oluşumdur. Bu oluşum, üye olsun ya da olmasınlar, ülkeler arasındaki füze ve teknoloji transferi alanındaki ilişkileri denetlemeyi amaçlamaktadır. ABD gibi bir gücün hegemonik şemsiyesi altında uluslararası bir inisiyatifin yaptırım gücüne sahip olması ise gerek eşitlik algısı gerekse kurumsallaşma bakımından sorunlu noktalara işaret etmektedir. ABD yaptırımlan tek taraflı bir şekilde uygulandığında, doğurduğu tepkiler nedeniyle, FTKR'nin meşruiyetini olumsuz bir şekilde etkilemektedir. ABD yaptırım kartına başvururken, kendi güvenlik endişelerinden ziyade FTKR ilkelerini öne çıkarsa dahi, bu durum önemli bir fark yaratmamakta ve eşitsizlik algısının giderilmesine yeterli gelmemektedir. Örneğin Hindistan'ın 2002-2007 arasında devlet başkanlığını yapmış ve aynı zamanda havacılık alanındaki uzmanlığıyla ülkesinin füze teknolojisini geliştirmesine katkı sunmuş Abdul Kalam, FTKR üzerinde hükümranlık kurmuş, ama Hindistan'ın füze programını boğmaya çalışıp da başaramamış ülkelerin tekelini kırmak amacıyla füze teknolojisini diğer ülkelere satmayı düşündüklerini belirtmiştir. ${ }^{81}$ 1999'da ABD'yi hedef alan bu görüş, açıkça, füze teknolojisi alanında hegemonya tesis etme çabalarına dönük tepkinin bir dişavurumudur. Her ne kadar ABD ve Hindistan arasında takip eden dönemde yapılan müzakereler yumuşamayı sağlamış ve nihai olarak bu yumuşama Hindistan'ın FTKR'ye üye olmasını kolaylaştırmışsa da Kalam'ın dile getirdiği tenkit, FTKR'nin ne denli kapsayıcı olduğunu sorgulama noktasında haklı noktalara işaret etmektedir.

Nitekim FTKR'nin üye portföyüne bakıldığında, 35 üyeden 21'inin NATO üyesi olması, geri kalan ülkelerin de büyük çoğunluğunun Batı bloğunda yer alması (Avusturya, Avustralya, Japonya vd.), FTKR'nin batı tandanslı bir oluşum olarak anılmasına yol açmaktadır. FTKR'nin

${ }^{81}$ United States Senate, "U.S.-Indian Nuclear Energy Cooperation: Security and Nonproliferation Implications a Compilation of Statements by Witnesses Before the Committee on Foreign Relations", Govinfo Resmi Web Sitesi, https://www.govinfo.gov/content/pkg/ CPRT-109SPRT24420/pdf/CPRT-109SPRT24420.pdf, s. 54 (Erişim Tarihi: 11.02.2020). 
Füze Teknolojisi Kontrol Rejimi:

ABD Merkezli Hegemonik Bir Yapıdan Normatif Bir Yapıya Geçişin Önemi

G-7'den neşet eden bir inisiyatif olduğu göz önüne alındığında, "seçkinler kulübü" ${ }^{2}$ yönündeki yerleşik algının değiştirilmesi ciddi zorluklarla karşı karşıyadır. ABD'nin ise bu seçkinler kulübünün lideri olduğu ve hasım olarak gördüğü ülkeleri FTKR üzerinden baskıladığı yönündeki yerleşik algı, bu oluşumun başarısının önündeki önemli bir engeldir. Örneğin ABD'nin, Güney Afrika gibi NPT'ye zaten dâhil olmuş ülkeleri FTKR'ye de katılmaya zorlarken dahi temel motivasyonu, güven duymadığı aktörlerin hareket alanlarını iyice daraltmak olmuştur. Zira Apartheid rejiminden sonra iktidarı devralan geçiş hükümetine FTKR'ye katılma yönünde bask1 uygulanarak, Nelson Mandela liderliğindeki Afrika Ulusal Kongresi'nin iktidara gelmesine koşut olarak Güney Afrika'nın füze kapasitesini geliştirmesi engellenmeye çalışılmıştır. ${ }^{83}$ ABD'nin gerek füze teknolojisinin yayılmasını, gerekse nükleer silahlanmayı önleme girişimlerinde esas olarak kendi önceliklerini gözetmeye çalışması, Neorealizm'in temel varsayımlarından olan, anarşik sistemde devletlerin temel hedefinin kendi güvenlik çıkarlarını maksimize etmek olduğu tezini doğrulamaktadır. Bu durumda, Neoliberal ekolün ABD'nin kurumsal iş birliğini esas alan, müstesna bir hegemonik güç olduğu iddiası noksan bir bakış açısı sunmaktadır. ${ }^{84}$

ABD'nin çifte standartlı davranışları kadar, izlediği tek taraflı politikalar da FTKR'nin etkinliğini zayıflatmaktadır. Örneğin Bush yönteminin 2001 yılında ABM Anlaşması'ndan çekilme kararı alması ve 2003'te Irak'1 işgal etmesi gibi yaşanan bir dizi gelişme, uluslararası güvenlik iklimini git gide kötüleştirmiştir. Irak işgali özelinde bakıldığında, bu hadise İran ve Kuzey Kore gibi ülkelerin füze geliştirme programlarını güçlendirmelerinde bir katalizör işlevi görmüştür. ${ }^{85}$ Benzer

${ }^{82}$ Gergoe Nirmala, "India Joins Elite Club of Countries Controlling Exports in Missile Technology", 27 June 2016, The Star, https://www.thestar.com/business/2016/06/27/indiajoins-elite-club-of-countries-controlling-exports-in-missile-technology.html (Erişim Tarihi: 11. 02.2020).

${ }^{83}$ Mistry Dinshaw, a.g.e., s. 86.

${ }^{84}$ G. John Ikenberry, a.g.e.

85 Waheguru Pal Singh (WPS) Sidhu, Masako Ikegami ve Sitk1 Egeli, "Too late for missile nonproliferation?", Bulletin of the Atomic Scientists, https://thebulletin.org/ 
bir kötümser trend, nükleer yetenek geliştirmek isteyen ülkelerin çoğalmasında da görülmüştür. ${ }^{86}$

Öte yandan $A B M$ ve INF gibi anlaşmaların ABD politikaları nedeniyle işlevsiz hale gelmesi, silahlanma sorununu tetiklemekte ve FTKR üzerinde ekstra bir baskı yaratmaktadır. Rusya Devlet Başkanı Vladimir Putin'in belirttiği gibi, ABD'nin ABM Antlaşması'ndan çekilmesinden sonra Rusya'nın hipersonik füzelere yatırım yapmaya başlaması, bu durumun belirgin bir tezahürüdür. ${ }^{87}$ Kötüleşen güvenlik ortamı, FTKR ve HCOC gibi teşebbüslerin işlevsizleştiği yargısına sebep olurken, Almanya'nın başlattığı the Missile Dialogue Initiative gibi yeni girişimlerle silahlanma sorununa yeni çözümler aranmaktadır. ${ }^{88} \mathrm{Bu}$ inisiyatif, INF gibi kritik anlaşmaların çökmesi sonrasında füze tehdidinden kaynaklanan risklerle ve bu risklerin, gelişen yeni teknolojilerle iyice kuvvetlenmesine cevap üretmek için hayata geçmiştir. ${ }^{89}$

$\mathrm{Bu}$ gibi inisiyatiflerin nasıl sonuçlar üreteceği cevap beklemekteyken, güvenlik tehdidinin dozunda artış gözlemleyen muhtelif aktörler ise çifte kullanımlı teknolojilere ve bilgiye ulaşımın kolaylaşması sayesinde FTKR kaidelerini ihlal eden sevk vasıtalarına erişmeye çalışmaktadırlar. ${ }^{90}$ Nitekim son dönemde gözlemlendiği gibi, füze envanterini geliştirmeye çalışan aktör sayısında gözle görülür bir artış kaydedilmektedir. Güney Kore'nin Kuzey Kore'den duyduğu tehdit

roundtable/too-late-for-missile-nonproliferation/ (Erişim Tarihi: 21. 07.2020).

${ }^{86}$ Eliza Gheorghe, "Proliferation and the Logic of the Nuclear Market", International Security, 2019, Cilt: 43, No. 4, 88-127.

87 TASS, "20 Questions with Vladimir Putin. Putin on the Army and the Arms Race", 2020, https://putin.tass.ru/en/ob-armii/ (Erişim Tarihi: 29.03.2020).

${ }^{88}$ Tanya Ogilvie-White, "Post-INF Arms Control in the Asia-Pacific: Political Viability and Implementation Challenges", IISS, 30 June 2020, https://www.iiss.org/blogs/researchpaper/2020/06/post-inf-arms-control-asia-pacific (Erişim Tarihi: 23.07.2020).

89 Political Declaration: Conference "2019. Capturing Technology. Rethinking Arms Control", 15 March 2019, https://www.auswaertiges-amt.de/blob/2199926/798daa3007fd8 fc2dddd04db13633353/190315-erkl-konf-rethinking-arms-control-data.pdf (Erişim Tarihi: 23.07.2020).

${ }^{90}$ Singh (WPS) Sidhu, Masako Ikegami ve Sitk1 Egeli, a.g.m. 
Füze Teknolojisi Kontrol Rejimi:

ABD Merkezli Hegemonik Bir Yapıdan Normatif Bir Yapıya Geçişin Önemi

nedeniyle FKTR limitlerinin ötesine geçen eylemler sergilemesi, İran'ın 3000 km'ye kadar menzile sahip balistik ve seyir füzelerine sahip olmas1, Kuzey Kore'nin FTKR limitlerinin çok ötesinde balistik füzeler geliştirmesi, bu kapsamda verilebilecek örneklerdir. Füze envanterlerini güçlendiren Hindistan, Pakistan, Türkiye, İsrail ve devlet harici bir aktör olarak Hizbullah da bu örnekler arasında eklendiğinde, kötümser tablo daha da belirginleşmektedir. ${ }^{91} \mathrm{Bu}$ gelişmeler karşısında FTKR, füze programlarını geliştiren muhtelif aktörleri dizginlemeye ve artan risk ve tehditlere cevap üretmeye gayret etmektedir. Böylece önleyici bir güvenlik mekanizması olarak işlevini sürdürmeye çalışmaktadır. $\mathrm{Bu}$ durum adeta zorlu bir "maratonu" andırmaktadır. Bunun içindir ki, FTKR'nin normatif olarak etkili bir organizasyon olması zaruridir. Nitekim, bu çalışmada vurgulandığı gibi, FTKR'nin bir parçası olduğu uluslararası rejimlerin ilgilendikleri konularda kalıcı bir düzelmenin sağlanabilmesi için, uluslararası aktörlerin düşünsel/kimliksel bir dönüşüm geçirmeleri önemli bir gerekliliktir.

ABD özelinde olduğu gibi, tek taraflı davranan, fayda maksimizasyonunu esas alan aktörlerin ön planda yer aldıkları oluşumlar, kolektif sorunlara çözüm üretirken meşruiyet sorunu yaşamakta ve böylece etki kapasiteleri sınırlı kalmaktadır. FKTR'nin asıl olarak normatif bir bağlam oluşturarak, aktörlerin kitle imha silahı ve füze tehdidinin önlenmesi prensibini içselleştirmelerine yardımcı olması gereklidir. Bunun için FTKR'nin geniş ölçekli bir sosyalizasyon sürecini mümkün kılacak bir norm difüzyonu ve düşünsel (ideasyonel) bir dönüşümün hayata geçirilmesine vesile olması önemli bir önkoşuldur. ABD merkezli faydacı-hegemonik bir yapıdan normatif bir yapıya geçiş, FTKR'nin başarısı açısından kilit önemdedir. Örneğin Sosyal

\footnotetext{
${ }^{91}$ Füze envanterleri ile ilgili genel bilgiler için bkz; CSIS Missile Defense Project, "Missiles of the World", https://missilethreat.csis.org/missile/ (Erişim Tarihi: 23.07.2020). Bu çalışmada sınırlı olarak değinilebilmiş Pakistan ve ayrıca Türkiye'nin füze programlan ile ilgili bkz; Jehangir Karamat, "Missile Acquisition by Pakistan: Military Strategic Imperatives", South Asian Survey, 2004, Cilt: 11, No: 2, 169-176; Sttk1 Egeli, "Turkey Embarks Upon Ballistic Missiles: Why and How?”, Uluslararast Illişkiler, Cilt: 14, No. 56, 2017, 3-22.
}

\section{9}

Güvenlik Stratejileri

Cilt: 16

Say1: 36 

Savaşı'ndan sonra anti-militarist bir eksende yeni kimlikler geliştirmeleri, içinde bulundukları farklı normatif yap1 ve bu yap1 dâhilinde tâbi oldukları sosyalizasyon sürecinin bir neticesidir. ${ }^{92}$ Keza Japonya'nın kitle imha silahlarına karşıt duruşu da benzer bir minvalde, şu şekilde açıklanmaktadır: tarihte atom bombası saldırısına maruz kalmış yegâne ülke olarak Japonya, edindiği yeni kimlik gereği bu silahlara karşı bir ülkedir. ${ }^{93}$

Japonya ve Almanya gibi ülkelerin ABD'nin baskılamasıly mı, yoksa İkinci Dünya Savaşı tecrübesinin beraberinde getirdiği "öğrenme" süreciyle mi pasifist bir kimlik geliştirdikleri, üzerinde hemfikir olunması zor bir konudur. Aktörlerin yeni bir düşünsel tasavvur geliştirmiş olmalarında büyük bir gücün baskısı rol oynamışsa dahi, yine de tecrübe edilen başkalaşım sürecinin önem ve değeri yadsınmamalıdır. Bununla birlikte, Neorealizm gibi maddi fayda eksenli Rasyonalist teorilere alternatif bir yaklaşım olarak ortaya çıkan Sosyal İnşacı teorinin de normatif/düşünsel bir dönüşümün gerçekleşmesinde ABD gibi hâkim güçlerin önemini yadsımadığı kaydedilmelidir. Örneğin Adler ve Barnet, devletler arası ilişkilerin barışçıl bir istikamette ilerlemesi için sosyalizasyon ve öğrenme süreçlerinin önemini vurgulamakla beraber, gerekli norm ve davranışların baskın bir güç sayesinde daha etkili bir şekilde yayılacağını belirtmektedir. ${ }^{94} \mathrm{Bu}$ iki yazara göre, merkezi bir gücün varlı̆̆1, bir "güvenlik toplumunun" oluşması ve olgunlaşmasına yardımcı olur, zira baskın bir güç sayesinde söz konusu bir gruba

${ }^{92}$ Thomas U. Berger, "Norms, Identity, and National Security in Germany and Japan", Peter J. Katzenstein (ed.), The Culture of National Security: Norms and Identity in World Politics, Columbia University Press, New York, 1996, 317-356.

${ }^{93}$ Jo-Ansie Van Wyk, "The International politics of Nuclear Weapons: A Constructivist Analysis", Scientia Militaria, South African Journal of Military Studies, 2007, Cilt: 35, No: 1, 1-28, s. 25-26.

94 Emanuel Adler ve Michael Barnett, "A Framework for the Study of Security Communities", Emanuel Adler ve Michael Barnett (ed.), Security Communities, Cambridge University Press, Cambridge, 1998, 29-65, s. 44-45. 
Füze Teknolojisi Kontrol Rejimi:

ABD Merkezli Hegemonik Bir Yapıdan Normatif Bir Yapıya Geçişin Önemi

liderlik, koruma, fayda ve amaç motivasyonu sağlanabilir. ${ }^{95}$ Bu mercekten bakıldığında, aktörlerin öğrenme süreçlerini şekillendirecek norm difüzyonu, hâkim bir güç etrafinda daha fazla etki kapasitesine sahip olur.

ABD, FTKR'nin işleyişinde başat güç olsa da bu oluşumun ihtiva ettiği norm ve ilkelerin devletler tarafindan içselleştirmesinin önkoşulu, ayrıcalıklı olan ve olmayan aktörler yönündeki algının kırılmasıdır. FKTR'nin kaidelerine uyulması konusunda kurumsal olarak bir eyleme geçilemediği ve böylece ABD'nin yaptırım kartının temel enstrüman olduğu göz önüne alındığında, mevcut yapının daha etkili bir şekilde işlemesi için kurumsallaşma alanında daha güçlü adımların atılması şarttır. ABD'nin FTKR'nin adeta "polisi" şeklinde görev ifa etmesindense, bu oluşumun kendisine ait bir izleme ve tetkik mekanizmasına sahip olması ve bunun üzerinden uluslararası camianın aktörleriyle etkileşim kurması önemli bir gerekliliktir. ${ }^{96}$ Çin, Pakistan, İran ve periferide yer alan ülkelerin balistik füze geliştirmek suretiyle caydırıcı kapasitelerini güçlendirme çabalarını Batı'nın engellemeye çalıştığı yönündeki intibalarının değiştirmesi için "meşruiyet açığı" olarak adlandırılabilecek sorunun ortadan kalkması ehemmiyet arz etmektedir.

$\mathrm{Bu}$ bağlamda, INF tarzında bağlayıcı bir antlaşmayla kaideleri belirlenmiş ve kendisine ait bir denetleme mekanizmasına sahip olmuş bir organizasyonun daha meşru, adil ve eşitlikçi bir düzelmede faaliyet göstermesi mümkün hale gelebilecektir. ${ }^{97}$ Özet olarak, kitle imha silahlarına ve bu silahları gönderebilecek unsurlara karşıt duruşun normatif bir zeminde temellenmesi için, ABD'nin baskısından ziyade, aktörlerin kendi kimliksel ve düşünsel özelliklerinden hareketle gerekli farkındalığı ulaşmaları önem arz etmektedir. Her ne kadar hegemonik bir güç uluslararası güvenlik alanında kolektif bir oluşumun hayata geçmesine ve kaidelerinin korunmasına ön ayak olmuşsa da FTKR'nin

\footnotetext{
${ }^{95}$ Emanuel Adler ve Michael Barnett, a.g.m., s. 52-54.

${ }^{96}$ Masako Ikegami, "Seeking a Path Toward Missile Nonproliferation", Bulletin of the Atomic Scientists, 2016, Cilt: 72, No: 6, 365-367, s. 366.

${ }^{97}$ Masako Ikegami, a.g.m., s. 366.
}

\section{1}

Güvenlik Stratejileri

Cilt: 16

Say1: 36 
862

Güvenlik Stratejileri

Cilt: 16

Sayı: 36 meşruiyeti ve etkinliği açısından hegemonik bir yapıdan normatif bir yapıya geçiş yapılması önemli bir gerekliliktir.

\section{Sonuc}

FTKR, "füze tehdidini önleme rejiminin" önemli bir bileșeni olarak uluslararası güvenliğe katkı sunan bir oluşumdur. Otuz yılı aşkın bir süredir faaliyette olan FTKR, kitle imha silahlarının farklı coğrafyaları tehdit etmesini önlemek amacıyla bir grup ülke tarafından hayata geçirilmişse de bünyesine yeni üyeleri katarak daha geniş bir iş birliği ağını mümkün kılmıştır. Bu bağlamda, özellikle ABD'nin baskısıyla, Rusya, Hindistan, Güney Afrika ve Brezilya gibi ülkelerin FTKR'ye dâhil olmaları, bu oluşumun dikkate değer başarılarıdır. FTKR; Çin ve İsrail gibi füze ve İHA üretiminde iki önemli ülkeyi üye olarak kazanamamışsa da bu ülkelerden rejim kaidelerine uyulacağı tahhüdünü alarak, enformel bir bağlamda kaidelerini daha geniş bir ölçeğe yayabilmiştir. İşlevi itibariyle FTKR, füze ihracatını menzil ve ağırlık bakımından belirli bir limitle sınırlamakta olup, bu limitin ötesine geçebilecek füzeleri ülkelerin, teknoloji ve ekipman transferiyle üretmelerini engellemeyi de kontrol kapsamına almıştır. FTKR 1987 yllında hayata geçmişse de ilerleyen yıllarda risk ve tehditlerin çeşitlenmesine paralel olarak yeni düzenlemeleri hayata geçirmiş ve kitle imha silahlarının muhtelif yollarla uluslararası güvenliğe yönelteceği tehlikeyi sınırlamaya devam etmiştir.

Diğer taraftan, FTKR'nin olumlu icraatlarına rağmen, gerek teknik gerekse meşruiyet eksenli olarak yaşanan noksanlıklar bu organizasyonun etkinliğini kısıtlamıştır. ABD'nin liderliğinde, gelişmiş batı ülkelerinin girişimiyle hayata geçen bir oluşum olarak FTKR, sistemin merkezinde yer almayan ülkelerin savunma kapasitelerini geliştirmelerini engelleyen bir girişim olarak görülerek, önemli bir meşruiyet sorunuyla karşılaşmıştır. "Teknolojik emperyalizm" olarak ifade edilebilecek bir bağlamda, füze teknolojisine halihazırda sahip olan gelişmiş ülkelerin, gelişmekte olan ülkelerin ihracat yoluyla askerî kapasitelerini geliştirmelerini engellemeye çalıştığı yönünde yaygın bir kanaat hâsıl olmuştur. Bu kanaat doğrultusunda belirli ülkeler, özellikle ABD'nin baskısına rağmen, füze teknolojisinin yayılmasının engellenmesi prensibine riayet etmeyerek, FTKR kurallarına tezat eylemler sergilemişlerdir. İran, Kuzey 
Füze Teknolojisi Kontrol Rejimi:

ABD Merkezli Hegemonik Bir Yapıdan Normatif Bir Yapıya Geçişin Önemi

Kore ve Pakistan gibi ülkelerin FTKR kaidelerine rağmen balistik füze sistemlerini geliştirme yolunda adımlar atmaları, füze unsurlarının ithalat ya da ihracatını gerçekleştirmeleri ve bu ülkelere Çin gibi ülkelerin teknolojik destek sunması, FTKR kaidelerinin etrafindan dolanabildiğini göstermiştir.

Meşruiyet eksenli olduğu gibi, teknik konularla ilişkili güncelleme eksiklikleri de FTKR'nin etkinliğini sınırlamıştır. 1980'li yıllarda seyir füzesi kategorisinde değerlendirilen İHA'lar, ilerleyen yıllarda, özellikle sivil alanda çok daha farklı amaçlarla kullanılmaya başlandığı için, bu unsurları füze kategorisinde değerlendiren FKTR'nin anakronik bir hal kazandığ 1 izlenimi doğmuştur. Ayrıca, FTKR'nin İHA'ların transferini engellemede yetersiz kalması, bunun etkinlik ve prestiji bakımından olumsuz sonuçlar doğurması ve İHA ihracatı gerçekleştiren ülkelerle iş birliği yolunun kapanması gibi farklı sorunlar da meydana gelmiştir. Öte yandan, bilgiye ulaşımın kolaylaşması ve çifte kullanımlı teknolojilerin yaygınlaşması, FTKR'nin önüne ilgilenilmesi gereken farklı sorunlar getirmiştir. Özellikle hipersonik füzelerin tedavüle girmesiyle birlikte farklı risk ve tehditler ortaya çıkarken, FTKR'nin bu gibi gelişmelere nasıl yanıt üreteceği belirsizliğini korumaktadır.

FTKR ile ilgili olarak bu çalışmanın altını çizdiği temel husus ise bu oluşum dâhilinde ABD hegemonyasının aşılması ve kurumsallaşma eksikliğinin giderilmesinin önemli birer gereklilik olduğudur. $\mathrm{Bu}$ çalışmada uluslararası rejimlere ilişkin sunulan teorik çerçeve üzerinden bu konu netleştirilmiştir. Öncelikle uluslararası rejimlerin uluslararası örgütlerden ayrı değerlendirilmesi gerektiği vurgulanmış ve "konubazlı" olarak rejimlerin, dünya sorunlarına çözüm bulma denemelerini anlamlandırma noktasında faydalı bir kavramsal çerçeve sunduğu belirtilmiştir. Bu minvalde rejim kavramının, iklim değişikliği, göç ya da silahlanma gibi sorunlara çözüm aranırken kolektif çabaların nasıl sonuç verdiğini anlama noktasında sşık tutan bir işlev gördüğü kaydedilmiştir. "Füze tehdidini önleme rejimi" de uluslararası rejimler arasında önemli bir başl1k olup, FTKR ise söz konusu rejimin önemli bir sütunudur. HCOC ve Wassenaar Düzenlemesi gibi teşebbüslerle birlikte FTKR, kitle imha silahı gönderebilecek araçların önlenmesi gibi bir misyonu yerine getirmeye çalışmaktadır. ABD ise FTKR çatısı 
864

Güvenlik Stratejileri

Cilt: 16

Sayı: 36

altında merkezi bir konuma sahiptir. Bu ülkenin yaptırım gücünü kullanan temel aktör olarak üçüncü ülkelerin füze teknolojisine erişimini engelleme çabas1, tabiatıyla FTKR'nin hegemonik bir aktörün şemsiyesi altında faaliyet gösteren bir oluşum olduğu izlenimini uyandırmaktadır. Her ne kadar ABD'nin baskısıyla birçok ülkenin FTKR normlarına uygun davranması sağlanabilmişse de belirli anlarda ABD'nin bizzat kendisi FTKR kaidelerini ihlal eden eylemler sergilemiştir. İsrail'in Arrow sistemlerini geliştirmesine teknolojik katkı sunmak, Büyük Britanya'ya Trident D-5 füzeleri satmak ve Güney Kore'nin FTKR kurallarını ihlal eden balistik füze geliştirmesine onay vermek, çifte standartlı eylemlere dair verilebilecek örneklerdir.

Neoliberal Kurumsalcı yaklaşım, büyük güç dahi olsalar devletlerin uluslararası oluşumların kurallarına riayet edeceğini varsaysa da bu hipotezin ABD özelinde gerçekliliği tartışmalıdır. Kurumsalcı yaklaşıma göre, uluslararası kurumlara üye devletler bir alanda kuralları çiğnerlerse gerek itibarlarının zedelenmesi gerekse diğer üye devletlerle ilişkilerinin farklı alanlarda da kötüleşmesi şeklinde olumsuzluklarla karşılaşırlar. Fakat ABD'nin, kuvvetle muhtemel, güç kapasitesi üstünlügünden hareketle, FTKR dâhil uluslararası oluşumların kurallarını esnetebilmesi, bu çıkarsamayla çelişmektedir. Bu minvalde, Neorealist bir bakış açısından, uluslararası örgüt ya da rejimlerin, esas olarak devletlerin çıkarlarına hizmet etmek amacıyla hayata geçirildikleri ve bu nedenle çıkarlar ile kurallar arasında bir seçim yapılması gerektiğinde, özellikle büyük güçlerin, iş birliğini bir kenara koyarak, çıkar maksimizasyonu dürtüsüyle hareket ettikleri varsayımı doğrulanmaktadır.

Bu saptamanın 1şı̆̆ında, "füzze tehdidini önleme rejiminin" kurucu sütunu olan FTKR'nin meşruiyetini ve etkinliğini güçlendirmesi için belirli başlı reform adımlarının atılması kaçınılmaz bir gerekliliktir. Bu adımların amacı, ABD merkezliliğin geride bırakılması ve uluslararası bir antlaşmayla çerçevesi belirlenmiş bir kurumsal yapının tesis edilmesi olmalıdır. ABD merkezli hegemonik bir yapıdan normatif bir yapıya geçişi esas alması gereken bu süreç, aktörlerin füze ve kitle imha silahlarından kaynaklanan tehdide yönelik düşünsel ve kimliksel bir farkındalık geliştirmelerine yardımcı olmayı hedeflemelidir. Devletlerin söz konusu tehdide dönük içinden geçecekleri sosyalizasyon süreci, 
Füze Teknolojisi Kontrol Rejimi:

ABD Merkezli Hegemonik Bir Yapıdan Normatif Bir Yapıya Geçişin Önemi

gerekli değer ve normların içselleştirilmesini gerekli kılmakta olup, istenen sonuçların alınması, kurumsallaşma yönünde adımların atılmasını gerekli kılmaktadır. Bunun için FTKR'nin kendisine ait bir kontrol ve yaptırım mekanizmasına sahip olması ve istişare ortamlarında devlet yetkililerinin söz konusu tehdide dönük ortak bir normatif ve düșünsel perspektif geliştirmelerinin sağlanması büyük önem arz etmektedir. Nitekim ABD'nin baskın konumuna rağmen, FTKR'nin siyasi olduğu gibi teknokrat bir mahiyete de sahip olması, kurumsallaşma yönünde bir altyapının olduğunu göstermektedir. Bilgi Değişimi, İzin ve Uygulama Uzmanları Toplantısı ve Teknik Uzmanlar Toplantısı gibi alt düzey istişare platformlarının varlığı bu hususa işaret etmektedir. Otuz yılı aşkın bir süredir FTKR'nin üye sayısını beş kat arttırarak ilgilendiği tehdit alanında bir süreklilik yakaladığı aşikârdır. Bu yapının kurumsallaşma yönünde atılacak yeni adımlarla, füze tehdidine dönük uluslararası bağlamda normatif bir dönüşümün gerçekleşmesine katkı sunması olanak dâhilindedir.

\section{Summary}

Since its inception in 1987, the Missile Technology Control Regime (MTCR) has served an instrumental mechanism in forestalling the missile proliferation threat. This initiative came into operation as a collaborative effort of G-7 countries, whose purpose in creating the MTCR was to prevent actors from acquiring or developing missile systems that are capable of delivering weapons of mass destruction. The MTCR's initial focus was on the threat of nuclear weapons, but later it incorporated the threat of chemical and biological weapons into its agenda. Therefore, the MTCR has become a comprehensive mechanism in the realm of tackling the threat of weapons of mass destruction and proved itself as a significant pillar of international security.

Although the MTCR kicked off as a rather modest organization with only seven members, it has expanded its member base by seven-fold over the years and has also shown a remarkably reformist streak by updating its technical capacity to address newly emerging threats. The measures to broaden the operational scope of the MTCR in 1992 and to 
tighten its control mechanism in 2003 attest to this. The MTCR still requires reform measures such as separating drones from missiles, since the former is increasingly being deployed for civilian usage, though it retains its utility as a military asset. Given the ability of MTCR members to implement updates and reforms when required, the MTCR beckons a promising future with regards to retaining its relevance as a collective security initiative. If one were to reflect upon some of the concrete achievements of the MTCR, it would suffice to highlight the cases of Russia, Brazil, South Africa and India, all of which agreed to adhere to the rules and norms of the MTCR and then to become full members of the organization. As some countries such as Russia had inherited a significant missile production infrastructure from the previous period of Cold War, the MTCR's ability to exact compliance from these actors to obey regime rules is a notable achievement regarding the prevention of the diffusion of missile technology and know-how.

Despite the MTCR's notable achievements, its effectiveness is hamstrung by legitimacy-related issues. Most notably, the MTCR yields an impression of an "elite club" led by the US, which allegedly seeks to impede the developing nations' path towards enhancing their defense capabilities through export of missiles and missile-related equipment. Some US policies attest to the validity of this claim such as providing technological or political support to ally countries like South Korea and Israel in a bid to help them expand their missile capabilities, even if doing so violates MTCR rules. While the US has often sanctioned developing nations as a result of their pursuit of missile programs, favorable treatment bestowed upon US allies indicates a problem of double-standard. But such behavior points to a bigger problem, which stems from the hegemonic position of actors such as the US within international organizations. As Neorealist theoreticians would argue, hegemonic powers that spearhead the creation of regimes and institutions often circumvent rules and principles when they clash with their interests. Although Neoliberal Institutionalists argue otherwise by asserting that hegemonic powers would refrain from breaching regime rules due to the fear of reputational costs, there seems to be scant evidence to back up this claim, as the US 
Füze Teknolojisi Kontrol Rejimi:

ABD Merkezli Hegemonik Bir Yapıdan Normatif Bir Yapıya Geçişin Önemi

has shown an inclination to act in a utilitarian-hegemonic manner under the MTCR.

As this work emphasizes, the real utility of international regimes lies in their ability to facilitate the normative transformation of party states in a given issue-area. This implies that, as opposed to rationalist theories, which highlight material-utility maximization as the main determinant of actor behavior, value-oriented behavior is what drives decision-making processes. This context explains why the MTCR's original focus must be on creating the conditions for states to internalize the norms and principles against missile proliferation, given missiles' ability to deliver weapons of mass destruction. It is argued in this work that international regimes fulfil vital functions in tackling a wide range of global problems such as armament, weapons of mass destruction, migration and climate change. The MTCR occupies a critical place within the broad regime of the prevention of missile threat along with the Wassenaar Arrangement and the Hague Code of Conduct against Ballistic Missile Proliferation. Although, the MTCR has proved itself as a viable collective security initiative in the realm of reducing missile threat, its effectiveness and legitimacy require overcoming US-centeredness through stronger steps towards institutionalization, which should provide the MTCR with its own inspection and sanctions mechanisms. The creation of a legal-normative framework based on an international agreement is a prerequisite for preparing the conditions, within which states may go through the required socialization process regarding missile and weapons and mass destruction threat and assimilate the corresponding ideational and normative elements into their identity. 


\section{8}

Güvenlik

Stratejileri

Cilt: 16

Say1: 36

\section{KAYNAKÇA \\ Kitaplar}

BROOKS, Stephen G. ve William C. Wohlforth. World Out of Balance: International Relations and the Challenge of American Primacy, Princeton University Press, Princeton, 2008.

BOWEN, Wyn Q., The Politics of Ballistic Missile Nonproliferation, 2000, Basingstoke: Macmillan.

CIRINCIONE, Joseph vd., Deadly Arsenals: Nuclear, Biological, and Chemical Threats, Carnegie Endowment for International Peace, Washington D.C, 2005.

FISHER, Richard D., China's Military Modernization: Building for Regional and Global Reach. Praeger Security International, Connecticut, 2008.

HASENCLEVER, Andreas vd., Theories of International Regimes, Cambridge University Press, Cambridge, 2004.

IKENBERRY, G. John. Liberal Leviathan. Princeton University Press, Princeton, 2011.

KATZENSTEIN, Peter J (ed.), The Culture of National Security: Norms and Identity in World Politics, Columbia University Press, New York, 1996.

KEOHANE, Robert, After Hegemony: World Political Economy Cooperation and Discord, Princeton University Press, New Jersey, 1984.

MASWOOD, S. Javed, The South in International Economic Regimes: Whose Globalization?, Palgrave Macmillan, Basingstoke, 2006.

MISTRY, Dinshaw, Containing Missile Proliferation: Strategic Technology, Security Regimes, and International Cooperation in Arms Control, University of Washington Press, Seattle, 2003.

PIFER, Steven, The Eagle and the Trident: U.S-Ukraine Relations in Turbulent Times, Brookings Institution Press, Washington, D.C, 2017.

ROEHRIG, Terence, Japan, South Korea, and the United States Nuclear Umbrella: Deterrence After the Cold War, Columbia University Press, New York, 2017.

WIRTZ, James J. (ed.), Weapons of Mass Destruction: An Encyclopedia of Worldwide Policy, Technology, and History (Volume II: Nuclear Weapons), Santa Barbara: ABC Clio, 2005.

\section{Makaleler ve Kitap Bölümleri}

ADLER, Emanuel ve Michael Barnett, "A Framework for the Study of Security Communities", Emanuel Adler ve Michael Barnett (ed.), Security Communities, Cambridge University Press, Cambridge, 1998, 29-65.

BAUER, Sibylle, "The Export Control Regimes", SIPRI Yearbook 2016: Armaments, Disarmament and International Security, Oxford: Oxford University Press, 2016, 758-767.

BERGER, Thomas U, "Norms, Identity, and National Security in Germany and Japan", Peter J. Katzenstein (ed.), The Culture of National Security: Norms and Identity in World Politics, Columbia University Press, New York, 1996, 317-356.

CHANKIN-GOULD, Sarah ve Ivan Oelrich, "Double-Edged Shield", Bulletin of the Atomic Scientists, 2005, Cilt: 61, No: 3, 36-41.

CHONG, Allen, "Revisiting the Missile Technology Control Regime: Fostering a New Norm for Ballistic Missiles", Canadian Foreign Policy, 1999, Cilt: 7, No: 2, 107-126.

DOYLE, Suzanne, "A Foregone Conclusion? The United States, Britain and the Trident D5 Agreement”, Journal of Strategic Studies, 2017, Cilt: 40, No: 6, 867-894. 
Füze Teknolojisi Kontrol Rejimi:

ABD Merkezli Hegemonik Bir Yapıdan Normatif Bir Yapıya Geçişin Önemi

DUNCOMBE, Constance ve Tim Dunne, "After Liberal World Order", International Affairs, 2018, Cilt: 94, No: 1, 25-42.

EGELİ, Sitk1. "Turkey Embarks Upon Ballistic Missiles: Why and How?", Uluslararası İlişkiler, Cilt: 14, No. 56, 2017, 3-22.

FINNEMORE, Martha ve Kathryn Sikkink, "International Norm Dynamics and Political Change", International Organization, 1998, Cilt: 52, No: 4, 887-917.

GHEORGHE, Eliza, "Proliferation and the Logic of the Nuclear Market", International Security, 2019, Cilt: 43, No. 4, 88-127.

HANSEN, Nelson E. "North Korean-Iranian Cooperation in Ballistic Missile Development", Jungmin Kang (ed.), Assessment of the Nuclear Programs of Iran and North Korea, Dordrecht: Springer, 2013, 115-127.

IKEGAMI, Masako. "Seeking a Path Toward Missile Nonproliferation", Bulletin of the Atomic Scientists, 2016, Cilt: 72, No: 6, 365-367.

KARAMAT, Jehangir, "Missile Acquisition by Pakistan: Military Strategic Imperatives", South Asian Survey, 2004, Cilt: 11, No: 2, 169-176.

KATZENSTEIN, Peter J., "Coping with Terrorism: Norms and Internal Security in Germany and Japan", Judith Goldstein and Robert O. Keohane (ed.), Ideas and Foreign Policy: Beliefs, Institutions, and Political Change, Cornell University Press, Ithaca, 1993, 265-295.

KEOHANE, Robert ve Joseph S. Nye, "Review: Power and Interdependence Revisited", International Organization, 1987, Cilt: 41, No: 4, 725-753.

KOBLENTZ, Gregory D, "Emerging Technologies and the Future of CBRN Terrorism", The Washington Quarterly, 2020, Cilt: 43, No: 2, 177-196.

KRASNER, Stephen D., "Transforming International Regimes: What the Third World Wants and Why", International Studies Quarterly, 1981, Cilt: 25, No: 1, 119-148.

KRASNER, Stephen D., "Structural Causes and Regime Consequences: Regimes as Intervening Variables", Stephen D. Krasner (ed.), International Regimes, Cornell University Press, Ithaca, 1983, 1-21.

MEARSHEIMER, John J., "The False Promise of International Institutions", International Security, 1994, Cilt: 19, No: 3, 5-49.

MEARSHEIMER, John J., "A Realist Reply”, International Security, 1995, Cilt: 20, No: 1, 82-93.

MEARSHEIMER, John J., "Bound to Fail: The Rise and Fall of the Liberal International Order', International Security, 2019, Cilt: 43, No: 4, 7-50.

MISTRY, Dinshaw ve Mark Smith, "Negotiating Multilateral Instruments Against Missile Proliferation", International Negotiation, 2005, Ciltt: 10, 425-451.

OZGA, Deborah A, "A Chronology of the Missile Technology Control Regime", The Nonproliferation Review, 1994, Cilt: 1, No: 2, 66-93.

RUGGIE, John Gerard, "International Responses to Technology: Concepts and Trends", International Organization, 1975, Cilt: 29, No: 3, 557-583.

SPEKTOR, Matias, "The Long View: How Argentina and Brazil Stepped Back from a Nuclear Race", 2015, Americas Quarterly, No: 57. 
870

Güvenlik Stratejileri

Cilt: 16

Say1: 36

SPEKTOR, Matias, "The Evolution of Brazil's Nuclear Intentions", 2016, The Nonproliferation Review, Cilt: 23, No: 5-6, 635-652.

PETERSEN, Charles C., "Moscow, Washington and the Missile Technology Control Regime", Contemporary Security Policy, 1995, Cilt: 16, No: 2, 1995, 44-71.

"Rumblings Precede 25th Missile-Control Meeting", Strategic Comments, 2011, Cilt: 17, No: 3, 1-3.

TARZI, Shah M., "International Regimes and International Relations Theory: Search for Synthesis", International Studies, 2003, Cilt: 40, No: 1, 23-39.

"The MTCR: Staying Relevant 25 Years On", Strategic Comments, 2012, Cilt: 18, No: 2, 1-3. U.S. GOVERNMENT PUBLISHING OFFICE. "Proposed Rules", Federal Register, 19 November 2018, Cilt: 83, N: 223, 58201-58202.

VAN WYK, Jo-Ansie, "The International politics of Nuclear Weapons: A Constructivist Analysis", Scientia Militaria, South African Journal of Military Studies, 2007, Cilt: 35, No: 1, 1-28.

WALTZ, Kenneth N., "Why Iran Should Get the Bomb: Nuclear Balancing Would Mean Stability", Foreign Affairs, 2012, Cilt: 91, No: 4, s.2-5.

\section{Raporlar}

BROCKMANN, Kolja ve Robert Kelley, "The Challenge of Emerging Technologies to Nonproliferation Efforts", SIPRI, April 2018.

EWERS, Elisa Catalano, vd., "Drone Proliferation Policy Choices for the Trump Administration", Center for a New American Security, June 2017.

SAYLER, Kelly M., Hypersonic Weapons: Background and Issues for Congress, 17 March 2020, https://fas.org/sgp/crs/weapons/R45811.pdf (Erişim Tarihi: 18.04.2020).

SPEIER, Richard H., K. Scott McMahon ve George Nacouzi, "Penaid Nonproliferation Hindering the Spread of Countermeasures Against Ballistic Missile Defense", Santa Monica, CA: The RAND Corporation, 2014.

SPEIER, Richard. H., "George Nacouzi, Carrie A. Lee ve Richard M. Moore, Hypersonic Missile Nonproliferation: Hindering the Spread of a New Class of Weapons", Santa Monica, CA: RAND Corporation, 2017.

TOLLEFSON, Scott D., "Brazil, the United States, and the Missile Technology Control Regime", Naval Postgraduate School, California, March 1990.

\section{İnternet Kaynakları}

"22 U.S.C. 2797b - Transfers of missile equipment or technology by foreign persons", https://www.govinfo.gov/app/details/USCODE-2009-title22/USCODE-2009-title22chap39-subchapVII-sec2797b/summary (Erişim Tarihi: 24.07.2020).

"1925 Geneva Protocol", https://www.un.org/disarmament/wmd/bio/1925-genevaprotocol/\#: :text=The $\% 201925 \% 20 \mathrm{Geneva} \% 20$ Protocol $\% 20$ prohibits,force $\% 20$ on $\% 2$ 08\%20February\%201928 (Erişim Tarihi: 28.09.2020).

ALLISON, George, "Britain's 1,000 Mile Punch - A Guide to the Tomahawk Cruise Missile", 7 August 2018, https://ukdefencejournal.org.uk/britains-1000-mile-punch-aguide-to-the-tomahawk-cruise-missile/ (Erişim Tarihi: 29.09.2020).

ARMS CONTROL ASSOCIATION, "The Missile Technology Control Regime at a Glance", July 2017, https://www.armscontrol.org/factsheets/mtcr (Erişim Tarihi: 15. 02.2020). 
Füze Teknolojisi Kontrol Rejimi:

ABD Merkezli Hegemonik Bir Yapıdan Normatif Bir Yapıya Geçişin Önemi

ARMS CONTROL ASSOCIATION, "Chemical Weapons: Frequently Asked Questions", June 2018, https://www.armscontrol.org/factsheets/Chemical-WeaponsFrequently-Asked-Questions (Erişim Tarihi: 20. 07.2020).

Best Practices for Effective Export Control Enforcement", https://www.wassenaar.org/ app/uploads/2019/consolidated/Best-Practices-for-Effective-Export-Control-

Enforcement.pdf (Erişim Tarihi: 21. 07.2020).

HERMAN, Arthur, "The Treaty Behind China's Drone Edge", 8 July 2019, The Wall Street Journal, https://www.wsj.com/articles/the-treaty-behind-chinas-drone-edge11562626340 (Erişim Tarihi: 12. 02. 2020).

GEORGE, Nirmala, "India Joins Elite Club of Countries Controlling Exports in Missile Technology", 27 June 2016, The Star, https://www.thestar.com/business/ 2016/06/27/india-joins-elite-club-of-countries-controlling-exports-in-missile-

technology.html (Erişim Tarihi: 11. 02.2020).

HOROWITZ, Michael C., "Drones Aren't Missiles, So Don't Regulate Them Like They Are", 26 June 2017, https://thebulletin.org/2017/06/drones-arent-missiles-sodont-regulate-them-like-they-are/ (Erişim Tarihi: 10. 01. 2020).

LDWO, "Report by the MTCR Chair: MTCR Chair addressed HCOC Plenary", 22 June 2016, https://mtcr.info/report-by-the-mtcr-chair-mtcr-chair-addressed-hcocplenary/ (Erişim Tarihi: 16. 01. 2020).

MISSILE DEFENSE PROJECT, "DF-11 (Dong Feng-11 / M-11 / CSS-7)", Missile Threat, Center for Strategic and International Studies, 29 January 2018, https://missilethreat.csis.org/missile/dong-feng-11/ (Erişim Tarihi: 16.02.2020).

MISSILE DEFENSE PROJECT, "Trident D-5", Missile Threat, Center for Strategic and International Studies, 15 June 2018, https://missilethreat.csis.org/missile/trident/ (Erişim Tarihi: 29.09.2020).

MISSILE DEFENSE PROJECT, "Missiles of the World", https://missilethreat.csis.org/missile/ (Erişim Tarihi: 23.07.2020).

MISSILE TECHNOLOGY CONTROL REGIME, https://mtcr.info/ (Erişim Tarihi: 05. 01. 2020).

MISSILE TECHNOLOGY CONTROL REGIME, "Guidlines for Sensitive MissileRelevant Transfers", https://mtcr.info/guidelines-for-sensitive-missile-relevant-transfers/ (Erişim Tarihi: 22. 07. 2020).

MISSILE TECHNOLOGY CONTROL REGIME, "Frequently Asked Questions (FAQS)", https://mtcr.info/frequently-asked-questions-faqs/ (Erişim Tarihi: 23.07.2020).

OGILVIE-WHITE, Tanya, "Post-INF Arms Control in the Asia-Pacific: Political Viability and Implementation Challenges", IISS, 30 June 2020, https://www.iiss.org/blogs/researchpaper/2020/06/post-inf-arms-control-asia-pacific (Erişim Tarihi: 23.07.2020).

PAYNE, Keith, "The Missile Technology Control Regime-European Involvement and Compliance Issues 2", 15 July 1998, Commission to Assess the Ballistic Missile Threat to the United States, Appendix III: Unclassified Working Papers, https://fas.org/irp/threat/missile/rumsfeld/pt2_payne.htm (Erişim Tarihi: 10.02.2020).

PINKSTON, Daniel, "The New South Korean Missile Guidelines and Future Prospects for Regional Stability", International Crisis Group, 25 October 2012, 
https://www.crisisgroup.org/asia/north-east-asia/korean-peninsula/new-south-koreanmissile-guidelines-and-future-prospects-regional-stability (Erişim Tarihi: 20.07.2020).

Güvenlik Stratejileri

Cilt: 16

Say1: 36 "Political Declaration: Conference "2019. Capturing Technology. Rethinking Arms Control"“, 15 March 2019, https://www.auswaertiges-amt.de/blob/2199926/798daa 3007fd8fc2dddd04db13633353/190315-erkl-konf-rethinking-arms-control-data.pdf (Erişim Tarihi: 23.07.2020).

PRINCIPAL DEPUTY UNDER SECRETARY OF DEFENSE, "Defense Planning Guidance, 1994-1999”, 29 February 1992. https://www.archives.gov/files/ declassification/iscap/pdf/2008-003-doc18.pdf (Erişim Tarihi: 29.03.2017).

REUTERS, "U.S., South Korea Agree to Revise Missile Treaty in Face of North Korean Threats", 2 September 2017, https://www.reuters.com/article/us-northkoreamissiles/u-s-south-korea-agree-to-revise-missile-treaty-in-face-of-north-koreanthreats-idUSKCN1BD034 (Erişim Tarihi: 22.02.20).

ROBLIN, Sebastien, "Saudi Arabia Already Has a Ballistic Missile Arsenal Courtesy of China-With a Little Help from the CIA", The National Interest, 22 September 2018, https://nationalinterest.org/blog/buzz/saudi-arabia-already-has-ballistic-missile-arsenalcourtesy-china\%E2\%80\%94-little-help-cia-31772 (Erişim Tarihi: 22. 07.2020).

SIDHU, Waheguru Pal Singh (WPS). Masako Ikegami ve Sttkı Egeli, "Too late for missile nonproliferation?", Bulletin of the Atomic Scientists, 22 August 2016, https://thebulletin.org/ roundtable/too-late-for-missile-nonproliferation/ (Erişim Tarihi: 21. 07.2020).

SPECTOR, Leonard S., "The Missile Technology Control Regime and Shifting Proliferation Challenges", April 2018, Arms Control Today, https://www.armscontrol.org/ act/2018-04/features/missile-technology-control-regime-shifting-proliferation-challenges (Erişim Tarihi: 26.07.2020).

TASS, "20 Questions with Vladimir Putin. Putin on the Army and the Arms Race", 2020, https://putin.tass.ru/en/ob-armii/ (Erişim tarihi: 29.03.2020).

TAYLOR, Jeffrey, "Public Statement from the Plenary Meeting of the Missile Technology Control Regime, Auckland", 11 October 2019, https://mtcr.info/publicstatement-from-the-plenary-meeting-of-the-missile-technology-control-regime-

auckland-11-october-2019/_(Erişim Tarihi: 08.01.2020).

"Text of the HCOC", https://www.hcoc.at/?tab=what_is_hcoc\&page=text_of _the_hcoc (Erişim Tarihi: 22. 07. 2020).

"THE MISSILE TECHNOLOGY CONTROL REGMIE (MTCR)", 08 January 2018, The Nuclear Threat Initiative, https://www.nti.org/learn/treaties-and-regimes/missiletechnology-control-regime-mtcr/ (Erişim Tarihi: 08. 03. 2020).

UNITED STATES SENATE, "U.S.-Indian Nuclear Energy Cooperation: Security and Nonproliferation Implications a Compilation of Statements by Witnesses Before the Committee on Foreign Relations, 7 November 2005, https://www.govinfo.gov/content/ pkg/CPRT-109SPRT24420/pdf/CPRT-109SPRT24420.pdf (Erişim Tarihi: 11.02.2020). 